\title{
PRISIONEROS ESPAÑOLES EN LA FRANCIA NAPOLEÓNICA. \\ EL MODELO POSITIVO DE LOS ESPACIOS DE CAUTIVERIO DE LOS \\ SUBOFICIALES, A TRAVÉS DEL DIARIO DE JOSE Ma ROMÁN (1808-1900)
}

\author{
MARÍA ZOZAYA ${ }^{1}$ \\ UNIVERSIDADE DE ÉVORA
}

\begin{abstract}
RESUMEN: El presente análisis se centra en mostrar el cautiverio de los suboficiales españoles durante la etapa napoleónica. Se basa en el estudio de caso del diario de José María Román (1809-1804), que es contrastado con las imágenes que aportan las fotografías de las casernas donde aquellos fueron recluidos en Nancy (1900). Se refleja parte del sistema de vida y las relaciones tejidas con los franceses. A la par, se ponen de relieve diversos aspectos que fueron causa $-\mathrm{y}$ consecuencia- del silenciamiento de aquella experiencia. Se plantea la existencia de un modelo de prisión relativamente positiva para los suboficiales durante las guerras napoleónicas, vinculado al momento de transición del Antiguo Régimen al Liberalismo.
\end{abstract}

PALABRAS CLAVE: Prisioneros de élite; modelo napoleónico; diario de ingeniero; ciudad prisión; casernas.

\section{SPANISH POWS IN NAPOLEONIC FRANCE: POSITIVE IMAGES OF CONFINEMENT SPACES OF NCO TROUGHOUT THE CASE STUDY OF JOSE Ma ROMAN (1808-1900)}

\begin{abstract}
This study analyzes Spanish prisoners of war (POW), the captivity system of Non Commissioned Officers (NCO) in Napoleonic France. Its principal source is the Memoirs of José María Román (1809-1814), which are contrasted with the postcards (1900) of the military caserne where they were confined in Nancy, before going to the city of Caudebec. It is shown the quotidian life and social networks they established with the French people. Are also shown the problems they had when they return back to Spain and had to hide that experience. We offer a positive image, a model of prison that -maybecould be generalized between NCO's POW during Napoleonic Campaigns in France (1808-1816). An almost unknown model which speaks about the transition from the Ancient Regime to the Liberalism.
\end{abstract}

KEY WORDS: Elite POW; Memoires; Napoleon's Model; “City Prison”; Military Caserne.

Recibido: 12-03-2014/Aceptado: 02-12-2014

\footnotetext{
${ }_{1}^{1}$ María ZOZAYA tiene una beca postdoctoral FCT del gobierno portugués en el CIDEHUS (Universidade de Évora, Portugal), donde ha completado esta investigación. Su estudio inicial del tema partió de un encargo de la Fundacion Lazaro Galdiano (en adelante FLG), y el desarrollo de diversas investigaciones posteriores se enmarcó en el proyecto "Grupos profesionales, corporativismo y políticas sectoriales del Estado", de Francisco Villacorta (CSIC); asimismo, "Elites Contemporaneas" de Pedro Carasa (GR-110, UVA).
} 


\section{INTRODUCCIÓN. LA PRISIÓN DE SUBOFICIALES DE LA ÉLITE EN ETAPA NAPOLEÓNICA, ¿UN MODELO OLVIDADO?}

El presente artículo es una aportación para ampliar en el conocimiento de las experiencias de los prisioneros de élite en tiempo de guerra. Está centrado en la época napoleónica, en el marco de transición del Antiguo Régimen al Liberalismo (1809-1814). En dicho contexto se sitúa el tratamiento de tales prisioneros en condiciones de vida relativamente positivas, ligadas los marcos del honor y al respeto de las jerarquías. Desde 1814, con el retorno de Fernando VII, tales experiencias de prisión fueron castigadas -y no premiadas como mérito de guerra-, por el miedo del contagio de afrancesamiento y por no considerarlo una experiencia patriótica. Por ello, los propios prisioneros las ocultaron de sus trayectorias militares públicas, guardándolos -en el mejor de los casos- en sus registros privados. En este sentido, la fuente principal es el Diario de José María Román, que es contrastado con imágenes novedosas de postales de 1900. Se relata parte de su experiencia junto con varios más de sus compañeros ingenieros militares, los suboficiales que fueron conducidos primero a Nancy y luego a Caudebec entre 1809 y 1814. No es objeto de este estudio la peor suerte que corrieron las más elevadas jerarquías, enviadas a castillos, ni la aún peor de los soldados rasos, quienes realizaron trabajos forzados y de similar naturaleza.

Sacar a la luz las condiciones positivas del cautiverio de aquellos ingenieros, puede contribuir a rescatar un modelo de prisión silenciado históricamente. Un modelo vinculado al mundo de los privilegios del Antiguo Régimen que ha sido ocultado o censurado por diversos motivos que se señalan. Aunque existen escasos estudios y experiencias conocidas que se mencionan, este tipo de contribuciones -junto a una deseada aparición de futuros análisis- pueden abrir un nuevo debate y sacar temas que muestran parte de una realidad desconocida e ignorada. El sacar a la luz estas visiones positivas de la prisión, puede ayudar a eliminar representaciones predominantes en el imaginario colectivo de naturaleza anacrónica o irreal en ciertas experiencias del pasado. 


\section{GRAN LAGUNA EN EL ESTADO DE LA CUESTIÓN. LA ESCASEZ DE LOS ESTUDIOS SOBRE PRISIONEROS DE ÉLITE EN EL PERIODO NAPOLEÓNICO}

Los episodios de la Guerra contra el Francés o Guerra de la Independencia (1808-1814) generaron tantos muertos como tinta para recordarlos; y tanta sangre derramada como para construir después una nación ${ }^{2}$. En el marco de las conmemoraciones, fuesen del 1900 o del 2000, se han estudiado con fruición múltiples facetas bélicas y políticas del periodo ${ }^{3}$, sean del cerco de Zaragoza ${ }^{4}$ o de España en general. En el plano legislativo, destaca la ingente producción vinculada a la Constitución de 1812. Abundan los análisis de sus correspondientes repercusiones en el cambio social, en la esfera pública o en la literaria ${ }^{5}$. Son también prolíficos los textos sobre la influencia que ambos hitos ejercieron en el plano internacional ${ }^{6}$. Es probable que sea, junto a la Guerra Civil de 1936 a 1939, el momento en que España más ha llamado la atención del ámbito académico mundial.

\footnotetext{
${ }^{2}$ Me refiero a las teorías que marcan como punto del nacimiento de la nación contemporánea este episodio, en la línea de JUNCO, José Álvarez: "La invención de la Guerra de la Independencia", Studia Historica-Historia Contemporánea, Vol. XII (1994), pp. 75-99. Un compendio retomando esa aportación y en los estudios de Antoni Moliner, Manuel Moreno, Pérez Garzón y otros, en: ZOZAYA, María: «Война за созАание нации? Испанская историография войны на Пиренеях 1808-1814 гг» («Une guerre pour la naissance d'une nation? L'historiographie espagnole des guerres des Pyrénées en 1808-1814»), en Annuaire d'études françaises, Les guerres napoleoniennes dans les historiographies nationales d'Europe et d'Amerique. Moscow, Russian Accademy, 2013, pp. 328-338.

3 Destaca la labor que desde hace años desarrollan: José M. PORTILLO; Bartolomé CLAVERO; Marta LORENTE: Pueblos, nación, Constitución: en torno a 1812, Vitoria-Gasteiz, Ikusager, 2004. Una visión general en: Antonio Moliner, La Guerra de la Independencia en España (1808-1814), Barcelona, Nabla, 2007. Un balance historiográfico Pedro RÚJULA: “A vueltas con la guerra de la Independencia”, HISPANLA, vol. LXX, núm. 235, (mayo-agosto, 2010), p. 461-492.

${ }^{4}$ Desde la Universidad de Zaragoza han realizado una importante labor: RÚJULA, Pedro; Canal, JORDI (Coords.), Guerra de Ideas, Fernando el Católico, Zaragoza, 2011. Las publicaciones también han sido promovidas por asociaciones locales como "Los sitios de Zaragoza" con sus premios anuales: Ramón GUIRAO, Las cinco villas de Aragón durante la guerra de la Independencia Española, Zaragoza, Ayuntamiento de Zaragoza, 2007. Las aportaciones en el respectivo plano de la ingeniería las recogen: CAPEL, Horacio; VVAA: Los ingenieros militares en España, repertorio bibliográfico e inventario de su labor científica y espacial, Barcelona, EU, 1988.

${ }^{5}$ Destaca la labor desenvuelta por la Universidad de Cádiz desde hace una década, que ha tenido especial fruición entre 2008 y 2012. Al respecto: Marieta Cantos; DURÁN, Fernando; ROMERO, Alberto: La guerra de pluma. Estudios sobre la prensa en Cádiz en el tiempo de las Cortes (1810-1814), Universidad de Cádiz, Cádiz, 2006. ${ }^{6}$ Repiensa la denominada crisis de 1812: PORTILLO, José María: Crisis atlántica: autonomía e independencia en la crisis de la monarquía hispánica, Madrid, Ambos mundos, 2007, pp. 21-24.
} 
Paradójicamente, el tema de los prisioneros sí que ha sido motivo de estudio en otras épocas y disciplinas; en ámbitos que van desde la vida cotidiana o la estrategia del castigo y el respeto, hasta el terreno jurídico que atañe a la experiencia social del cautiverio ${ }^{7}$. Sin embargo, diversas facetas han quedado muy olvidadas, y pueden dar lugar a imágenes atípicas, como la que aquí nos atañe de las formas de vida positivas de los suboficiales prisioneros de elite ${ }^{8}$.

Esa laguna se gesta en un marco generalizado de olvido. En un plano internacional general, los cautivos durante el primer Imperio napoleónico han sido bastante relegados. Aunque algo se han tratado. Francisc Abell ya sacó a la luz la experiencia de numerosos prisioneros en tierras y mares ingleses ${ }^{9}$; Gavin Daly se ha especializado en el estudio los del caso británico; MacDougall en los confinados en Escocia; Patricia Crimmin en los de las comunidades británicas portuarias ${ }^{10}$. Otros investigadores de la Europa del Este se han centrado en las experiencias de la Rusia y Ucrania napoleónica ${ }^{11}$. En el caso de

\footnotetext{
7 Mucho más abundantes son los dedicados a la vertiente jurídica desde la disciplina penal, donde sentó precedente en España: TOMÁS y VALIENTE, Francisco: El derecho penal de la monarquía absoluta (S. XVIXVIII), Madrid, Tecnos, 1969. Asimismo, en el plano de la Historia: Justo Serna, Presos y Pobres en la España del XIX, Barcelona, PPU, 1988. En otras épocas de la Historia, destaca la nueva visión aportada en el campo medieval que rescata la faceta relativamente humanitaria, en el monográfico: FIERRO, Maribel; GARCÍA FITZ, Francisco: El cuerpo derrotado: cómo trataban musulmanes y cristianos a los enemigos vencidos, CSIC, Madrid, 2008. OLIVER, Pedro: "El concepto de control social en la Historia Social. Estructuración del orden y respuestas al desorden", Historia Social, no 51, 2005, pp. 73-91.

8 Señala igualmente tal vacío: DALY, Gavin: "Napoleon's lost regions: French prisoners of war in Britain, 1803-1814”, History: Journal of the Historical Association, 89 (3, 2004), pp. 361-80, p. 362. Hace poco ha insistido en los vacíos que existen, en: DALY, Gavin: "Liberators and Tourists: British Soldiers in Madrid during the Peninsular War", en: Palgrave MACMILLAN, Catriona KANNEDY; Matthew McCORMACK (ed): Soldiering in Britain and Ireland, 1750-1850: Men of Arms, Basingstoke, 2013, p. 117. Llamé la atención al respecto en: ZOZAYA, María: "From Saragossa to France: Changes Through the vision of a Napoleonic State Prisioner". Napoleon and the Transition to the Modern World. VIIIht International Napoleonic Congress, INS. Sant Anton, Malta, 16-VII-2010. Para cubrir este vacío - de la que son muy aclarativas las experiencias de la primera Guerra Mundial- han reunido aportaciones: Ana Paula Pires; Jacob Zollman (Coords.). Prisoners of war in the twentieth century. Actors, concepts and changes, Lisboa, 24/25-XI-2014.

9 ABELL, Francis: Prisoners of War in Britain, 1756 to 1815. A record of their lives, their romance and their sufferings. Humphrey Milford, London, Oxford University Press, 1914.

10 DALY, Gavin: "Napoleon's lost regions: ...; MAC-DOUGALL, Ian: All Men Are Brethren: Prisoners of War in Scotland, 1803-1814, Scotland, John Donald, 2008. Cabe destacar el estudio de las comunidades británicas portuarias de CRIMMIN, Patricia K.: "Prisoners of war and British Port Communities, 1793-1815", Le northern Marinier VI, n.4 (Oct. 1996), pp. 17-27.

11 De especial interés para estos estudios me resultó el Congreso de la International Napoleonic Society celebrado en Moscú en 2012, donde se conectaban los estudios de la Europa occidental con la eslava, Rusia y Ucrania. Respectivamente: KHOMCHENKO, Sergey: "French Prisoners in Russia and the Local Population"; Alexander Sagomonyan, "The Spanish military contingent in the Grande Armée"; JOOR, Johan: "Nous continuons à être inondés de pamphlets et d'affiches", 10th Congress of the INS, Moscow, Russian Academy of Sciences, 9-12/VII/2012. También present comunicación y fue publicada: ZEMTZOV V. "Les prisonniers de l'armee de Napoleon dans les usines de l'Oural ou comment les Russes sont tombes deux fois dans le meme panneau", pp. 101-114; "L'ennemi et la frontiére: transformation de l'image de l'autre", pp. 115126; PROMSLOV, Nicolai; YU, Mikhailova: "Memoires de soldats de la Grande Armee sur la Pologne et la Lituanie", pp. 272-288; en Annuaire de Études Françaises, ВОЙНА 1812 ГОАА В ГАОБАЯЬНОМ KOHTEKCTE, Moscow, 2014.
} 
los prisioneros de élite portugueses, Climaco y Guardado han sacado a la luz hace poco otro caso de depósitos con condiciones atípicas en la Francia napoleónica ${ }^{12}$.

En particular, los prisioneros españoles en etapa napoleónica han sido especialmente olvidados; aunque, por suerte, existen análisis al respecto. Primero, se han estudiado los soldados del marqués de la Romana. Éstos pasaron de ser aliados del ejército napoleónico -en virtud de las alianzas de Fernando VII-, a ser prisioneros de ellos, con el consecuente periplo por la Europa en guerra ${ }^{13}$.

En segundo lugar, destacan los trabajos sobre situaciones extremas. Así, los prisioneros conducidos desde Cádiz a la isla española de Cabrera. Allí fueron olvidados a su suerte la suma inicial de siete mil prisioneros franceses, a los que se sumó un contingente de un total de trece mil $^{14}$. Soldados quienes pasaron años en condiciones infrahumanas, sin apenas alimentos ni recibir la mínima atención de barcos con provisiones, en una isla que ya de por sí contaba con escasos medios de abastecimiento e infraestructuras. Entre los motivos de que su cautiverio haya sido objeto de análisis se cuenta sin duda la existencia de fuentes que hablan sobre las dimensiones de la tragedia. Contaron con los relatos de muchos de sus supervivientes, quienes reaccionaron escribiendo con el ánimo de denunciar mediante el recuerdo ${ }^{15}$. Décadas después, llamó la atención de sus estudiosos lo inusual de las condiciones extremas del confinamiento ${ }^{16}$. En ese rescate de la memoria, sus instalaciones y barracas son de las pocas que cuentan con excavaciones, probablemente por el motivo casual de encontrarse en el camino del yacimiento arqueológico de las tumbas visigodas de la isla (ver apéndice, Imagen 1).

\footnotetext{
12 Agradezco inmenso el envío de este manuscrito de: CLIMACO, Cristin; GUARDADO, Carlos: «Prisioneiros portugueses em França durante a Guerra Peninsulan», en: ROCHA, Jorge Silva (Org.),XXII Colóquio de História Militar: Portugal na Guerra Peninsular: 1812-1815: Do cerco de Ciudad Rodrigo ao Congresso de Viena: o caminho para a derrocada do Império Napoleónico, Lisboa, Comissão Portuguesa de História Militar, 2014, pp. 337-363.

${ }^{13}$ Ha sido tratado por: MöRNER, Magnus: El Marqués de la Romana y el Mariscal Bernadotte la epopeya singular de la División del Norte en Dinamarca (1808), Madrid, CEPC, 2004. COSTA, Miquel; PINYA, Romà: El Marqués de la Romana: l'expedició a Dinamarca (1807-1808), Mallorca, El Tall, 1990. CASSINELLO, Andrés: El Capitán General Marqués de la Romana (1761-1811), Aranjuez, Doce Calles, 2012.

14 Apunta que fueron siete mil prisioneros a la llegada: Miguel Benássar, Cabrera: La junta gubernativa de Mallorca y los prisioneros del ejército napoleónico, Palma, Ajuntament de Palma, 1988. PELLISER, Pierre; PHELIPEAU, Jèrôme: Les grognards de Cabrera, 1809-1814, Paris, Hachette, 1979.

15 Puede ser el fenómeno generado por el recurso a la memoria para superar la traumática experiencia de una guerra, denunciándola para que no volviera a acontecer, similar a la que relatase FRASER, Ronald: Recuérdalo tú y recuérdalo a los otros. Historia oral de la Guerra Civil Española, Barcelona, Crítica, 2007.

${ }_{16}$ Además de los citados PELLISER, Pierre; PHELIPEAU, Jèrôme: Les grognards..., el caso de Cabrera fue estudiado por: SMITH, Dennis: The prisoners of Cabrera, London, Four Walls, 2001.
} 
En tercer lugar, algunos investigadores se han especializado en el tipo de estudios particulares que aquí nos ocupan. Geisendorf, o Aymes son apenas los que abordan prisioneros españoles en Francia a partir del primer imperio napoleónico ${ }^{17}$, y en algunos de los casos sí hablan de situaciones equivalentes, relativamente positivas. Otras tesis recientes permitirán en un futuro comparar circunstancias similares ${ }^{18}$. Existen ediciones de otras experiencias positivas ya más sorprendentes como la maravillosa aventura del supuesto franciscano, el sargento Mayoral ${ }^{19}$.

\section{UN POSIBLE MODELO DE CONFINAMIENTO DEL RANGO MEDIO ¿AÚN POR DESCUBRIR?}

De cualquier modo, los trabajos mencionados son muy escasos para la importancia que este género requiere. A mi juicio, los cautiverios de élite en terreno extranjero supusieron una aportación singular para las vivencias personales, reflejadas también en una cualificación de la experiencia profesional y el movimiento intelectual que generaron a la postre en Europa ${ }^{20}$.

En efecto, cuando he analizado a fondo el caso de los prisioneros en Nancy y Caudebec, aparece una nueva imagen de la experiencia en cautiverio. Desaparece el imaginario negativo que en general predomina cuando se mencionan las formas de reclusión para los desplazados. En la misma línea, los estudios ya citados de Daly, MacDougall o Crimmin, en ocasiones refieren condiciones de vida relativamente positivas de los suboficiales en el cautiverio ${ }^{21}$. También se puede extraer del estudio de Cristina Clímaco

\footnotetext{
17 Théophile Geisendorf-Des Gouttes, Les Prisonniers de guerre sous le Premier Empire, Ed. Labor Nelle, 1932. Siguió sus pasos AYMES, Jean-René: Los españoles en Francia (1808-1814). La deportación bajo el primer Imperio. Madrid, Siglo XXI, 2008.

${ }_{18}$ Me refiero a las Tesis Doctorales citadas por: CLIMACO, Cristina; Carlos GUARDADO: «Prisioneiros portugueses em França..., pp. 337-338; en concreto, y que no he podido consultar: ROUANT, David: Les prisonniers de guerre étrangersdans le Nord-Est de la France (1803-1814), dirigida por BOUDON, Jacques Olivier: Université Paris-Sorbonne, 2009. Didier Houmeau, Les prisonniers de guerre britanniques de Napoléon Ier, dirigida por Philippe Chassaigne, Université de Tours, 2011.

19 MAYORAL, Francisco: Historia verdadera del Sargento Mayoral escrita por él mismo, Ed. crítica de DURÁN, Fernando), Cádiz, Espuela de Plata, 2008.

${ }^{20}$ Como demostré en ZOZAYA, María: "Spreading Ideas. The Intellectual Movement Throughout the Spanish Captives in France (1809-1836)", II International Symposium of the XIXth-Century Hispanists Network, Cádiz, Universidad de Cádiz, 18-V-2012. También ha señalado brevemente la importancia del "cross-cultural contact" en: DALY, Gavin: "Liberators and Tourists..., p. 117.

${ }^{21}$ MAC-DOUGALL, Ian: All Men Are Brethren: Prisoners of W ar in Scotland, 1803-1814, Scotland, John Donald, 2008. Cabe destacar el estudio de las comunidades británicas portuarias de CRIMMIN, Patricia K.: "Prisoners of war..., pp. 17-27.
} 
para los prisioneros portugueses que fueron enviados a la Francia napoleónica ${ }^{22}$, cuyas condiciones se asimilaban en algo a las que se muestran a lo largo de estas páginas.

Tales tratamientos relativamente positivos de los cautivos rompen con la imagen consolidada de forma tradicional (es probable que nacida de la experiencia de los soldados rasos). En ese ámbito, son comparables a los resultados ofrecidos por Martínez-Radio en sus estudios sobre prisioneros de elite del Antiguo Régimen ${ }^{23}$. Estableciendo parangones trasversales en un plano espacial y cronológico, durante la Primera Guerra Mundial hubo casos en que se mantuvo un tratamiento especial para las jerarquías. Como el de los prisioneros alemanes en Angra de Heroísmo, divididos en tres clases, cuyas condiciones de vida se vinculaban al estatus de cada cual, con situaciones en materia de higiene y sanidad que eran comparativamente mejores a las de los propios ciudadanos de la zona ${ }^{24}$.

El caso aquí analizado se centra en las jerarquías medias, de las que aún queda mucho por estudiar. Es decir, no abordamos a los prisioneros del máximo escalafón, a personajes destacados como Blake, Palafox, Amarillas o Contreras, quienes fueron confinados y aislados en Castillos. Tampoco analizamos a los soldados rasos, muchas veces obligados a hacer trabajos forzados. La experiencia que aquí analizamos se centra en los suboficiales, ingenieros militares de rango superior, que formaban parte de las jerarquías, pero que no eran las cabezas dirigentes.

De ese conjunto de suboficiales, aquí se ofrecen resultados lejanos a la visión terrible del prisionero de guerra. El estudio de los cautivos españoles en terreno francés de 1809 a 1816, muestra un mundo algo confortable. En esa experiencia se establecieron formas de sociabilidad cotidiana ${ }^{25}$, se trazaron unos lazos intelectuales estrechos y se tejieron múltiples redes sociales con el vecino francés, que en absoluto se corresponden con la imagen negativa posterior predominante del cautiverio ${ }^{26}$. Desvelar, poco a poco

\footnotetext{
22 CLIMACO, Cristina; Carlos GUARDADO: «Prisioneiros portugueses em França ..., pp. 338-339.

23 Cabe señalar que Martínez-Radio se ha especializado en la etapa previa de la guerra de Sucesión, si bien sus estudios de las formas de vida son comparables a las de los prisioneros en la época napoleónica. También cuenta con estudios de la época que aquí concierne, aunque se trata de casos puntuales del principio de la contenda, en 1808, que en Espanha son instigados, acusados de posible afrancesamiento (por lo que se trata de casos diferenciados), MARTÍNEZ-RADIO, Evaristo: "Herederos de Irlanda al servicio de España durante la Guerra de la independencia. El caso del primer batallón del regimento Hibernia", Trocadero, no 25 (2013), pp. 161-185, p. 175.

24 REZENDES, Sérgio: A grande Guerra nos Açores. Memória histórica e património militar, São Miguel, Açores, Ed. Letras Lavadas, 2014, pp. 81-91; sobre las tres clases, pp. 89-90.

$25 \mathrm{Al}$ igual que sucede en otros casos recientes, como ha estudiado: BARROSO, Ana M.: Redes de sociabilidade numa prisão feminina, Evora, Universidade de Evora, 1999.

26 A mi juicio, esa deformación se debe a la dura experiencia del tratamiento de los prisioneros en la Primera y Segunda Guerras Mundiales. En especial, a la traumática de los campos de concentración, que ha borrado la imagen de aquel pasado del prisionero napoleónico suboficial casi desconocido. Así lo mostré en: ZOZAYA, María: "Denyed Memory Spaces. Collective Memoirs not Shared in the Past. Looking back from the XXth Century Experience to the Elite Prisoners of the Peninsular War", en: PIRES, Ana Paula; ZOLLMAN, Jacob (Coords.). Prisoners of war in the twentieth century. Actors, concepts and changes, Lisbon, 24/25-XI-2014.
} 
aquellas condiciones de los prisioneros de guerra de elite españoles en Francia permitirá acabar con aquellas imágenes tergiversadas por motivos de diversa índole en el imaginario colectivo de la Historia.

\section{LA OCULTACIÓN. UNA FUENTE ESENCIAL PARA TRATAR EL PERIODO EN PRISIÓN, 1809-1814}

A mi juicio, la mencionada ausencia de estudios sobre prisioneros de elite entre $1808 \mathrm{y}$ 1814 para el caso español se debe sobre todo a la falta de fuentes. Falta de documentos que hablen en privado y en primera persona, como los diarios que relatasen la vida cotidiana del cautiverio. En lo que respecta al plano personal, he podido comprobar cómo la prisión en Francia fue un tema bastante silenciado en la época fernandina. Les sobraban los motivos para aquel ocultamiento ${ }^{27}$. En efecto, tras 1814, se hizo recomendable pasar por alto la experiencia de ese cautiverio relativamente "positivo" en Francia, debido a varias razones. Primera, de cara a la sociedad que había sufrido una penosa guerra contra los franceses, tras la cual mostraba signos de xenofobia y odio contra todo elemento relacionado con el país vecino y con un posible afrancesamiento ${ }^{28}$.

Segunda, convenía ocultar aquella experiencia de cara al recelo del propio Estado español y de sus poderes. Los antiguos prisioneros querían pasar con la mayor levedad posible el difícil proceso de depuración castrense del régimen de Fernando VII ${ }^{29}$. Temían en especial el examen ante el tribunal militar, a menudo injusto e infundadamente agresivo. El rey, en su regreso al poder, "purificó" en todos los ámbitos; hizo procesos dilatados incluso entre quienes se suponían de mayor confianza, como los empleados allegados de palacio $^{30}$. En lo que respecta a los antiguos prisioneros, en la teoría aventajó a quienes peor lo habían pasado, considerándolo como un servicio de guerra (aunque la mayoría de las jerarquías confinadas en castillos y fortalezas en realidad sufrieran igual purga). Mientras, castigó a quienes entre 1809, 1814 y 1816 hubieran estado cautivos pero en regímenes de media libertad. Es decir, castigó a quienes no llevaron grilletes ni estuvieron aislados en

\footnotetext{
${ }^{27}$ Los expuse en: ZOZAYA, María: «Entre el secreto privado y la luz pública. La acción de las vicisitudes conmemorativas en el diario personal de un ingeniero, 1808-2012», en: Dos siglos llaman a la puerta: 1812-2012. VIII Congreso Internacional Doceañista, Cádiz, Universidad de Cádiz, 14-V-2012. Conferencia disponible en: http://mariazozaya.wordpress.com/2012/03/16/de-la-esfera-privada-a-la-luz-publica/

28 ARTOLA, Miguel: Los afrancesados, Barcelona, Altaya, 1997.

${ }^{29}$ AYMES, Jean-René: La Guerra de la Independencia en España, Madrid, SXXI, 2008.

30 MORAL, Antonio M.: "Del Rey abajo, ninguno" La depuración política de la Real Casa y Patrimonio durante la Crisis del Antiguo Régimen (1814-1835), Historia Contemporánea, n. 29, 2004, pp. 895-925; 899.
} 
castillos ni se intentaron escapar ${ }^{31}$. Condiciones que reunían muchos de los compañeros de Román (en teoría él no, unos días antes de la derrota de Napoleón en 1814 quedó oculto en Caudebec en vez de seguir hasta el siguiente depósito de Caen). En muchos casos, dicha depuración duró dos años, incluso para aquellas cabezas militares que habían estado reclusos en castillos e incomunicados ${ }^{32}$, pese a que en teoría se les debía condecorar por servicios de guerra.

Por ello, muchos de estos suboficiales prisioneros de élite, temiendo el castigo, tendieron a ocultar después la prisión en Francia. He comprobado cómo varios de los compañeros de Román resumieron aquella experiencia de cinco años en cautiverio en apenas una línea en el expediente militar personal ${ }^{33}$. Asimismo, en el entorno de los ingenieros militares, fue reproducida esa ocultación de la experiencia concreta en los depósitos de Nancy y Caudebec. Una buena muestra es el hecho de que casi desapareció del registro biográfico de Mariano Salas, una de las encomiables reseñas de la trayectoria de los ingenieros militares de la Real Academia que fueron conducidos prisioneros desde Zaragoza al país vecino. En el caso de José $\mathrm{M}^{\mathrm{a}}$ Román, es del único de quien Mariano Salas menciona que estuvo en Caudebec, y sólo para decir que se fugó ${ }^{34}$ (donde sin embargo estuvo sólo unos meses de 1814, y con todos sus compañeros). Respecto a la experiencia de Nancy (que duró más de cuatro años y en ella estuvieron todos los compañeros de Román junto a él mismo), Salas hace la única referencia de que allí fueron Saint-Marq y José Antonio de Aragón-Azlor. Por suerte para la memoria colectiva que aquí tratamos de recuperar, hace una mención indirecta donde alude a que fue compartida la experiencia de ése último, familia de los duques de Villahermosa: "Prisionero por la capitulación, fue conducido al depósito de Nancy donde con los cuantiosos recursos que le enviaba su ilustre madre, tuvo la satisfacción de atender noblemente al socorro de sus desgraciados

31 Compila los decretos: HOCQUELLET, Richard. "Una experiencia compleja. La guerra de la independencia a través de la trayectoria de algunos de sus actores", en DEMANGE; GÉAL; HOCQUELLET, MICHONNEAU; SALGUES (Coords.), Sombras de mayo. Mitos y memorias de la Guerra de la Independencia en España (1808-1908), Madrid, Casa de Velázquez, 2007, pp. 41-59

32 Fue el caso de Joaquin Blake, como relató en sus cartas al marqués de las Amarillas, quien le felicitaba pese a la larga espera- a la par que él se quejaba amargamente de no haber pasado la depuración. Así se muestra en las cartas recogidas por: BENAVIDES, Nicolás; YAQUE, José A.: El Capitán General don Joaquín Blake y Joyes, Madrid, SGE, 1960.

33 ZOZAYA, María: «Entre el secreto privado y la luz pública...

34 Cuando sin embargo en Caudebec estuvieron varios de los compañeros de Román. Ni mucho menos se detalla apenas el lugar en la obra de Mariano Sala. Del propio Román, ni siquiera Sala menciona que estuviese en Nancy, y es del único de todos sus compañeros que se dice que estuvo en el segundo depósito: "Prisionero en Francia, pudo fugarse del depósito de Caudebec (Normandia) en marzo de 1814". SALAS, Mariano: Obelisco bistórico en honor de los heroicos defensores de Zaragoza en sus dos sitios, Zaragoza, Salas-Arzobispo, 1908, p. 130. La obra de Salas es una recopilación magnífica, que tal vez silenció este aspecto debido a que ya partía de un silenciamiento en los expedientes militares que él recopilaba, o al desconocimiento, a las tendencias nacionalistas de la época, o a objetivos de resumir y prestar poca importancia a esta aventura desconocida. 
compañeros de cautiverio"35. De esos "desgraciados compañeros” Salas sin más alude a que estuvieron "en Francia” sólo varios de ellos. Fueron: Zappino, Font, Velasco, Quiroga y otros que también menciona de manera puntual Román, con quienes compartió su estancia de cinco años en Nancy y Caudebec ${ }^{36}$. Incluso, Salas silencia los lugares delos depósitos para otros casos -como Cortines-, que no pudieron escapar del siguiente destino de Caen, y estuvieron en Francia hasta $1816^{37}$. Al cruzar tales fuentes silenciadas y silenciadoras con el registro privado del Diario de Román, puede pensarse que el tipo de experiencia que con él se recompone, sea extrapolable a los compañeros mencionados, e incluso a muchos más de los individuos de los depósitos franceses de Nancy y Caudebec. Es probable que esa situación fuese extensible a muchos más prisioneros del Estado Francés, pues sus mandatarios se indignaban al enterarse de las noticias del tratamiento denigrante que sus conciudadanos sufrían en territorio español ${ }^{38}$.

Por todo lo señalado, en 1814 y años posteriores, fue común no registrar ni sacar a la luz la experiencia como prisioneros. En los casos en que se escribieron memorias del cautiverio, y que además lograron conservarse tras la experiencia bélica, a menudo se olvidaron con el paso de los años. Tras fallecer su autor, perdieron su significado y sus manuscritos -como el que aquí nos ocupa- pasaron a confundirse entre los fondos de alguna biblioteca ${ }^{39}$. Por ese conjunto de factores, que van dese la dificultad del proceso de creación de un diario en tiempo de guerra y cautiverio, hasta su preservación durante la represión política, o a su posterior recuperación, hay que destacar el valor de registros

\footnotetext{
35 Sólo se concreta que estuvieron en Nancy el general Felipe de Saint-Marcq; y el duque D. José Antonio de Aragón-Azlor y Pignatelli, de los duques de Villahermosa, de quien Sala menciona que en Francia además ayudaba a sus compañeros con los víveres y dinero que le enviaba su madre. SALAS, Mariano: Obelisco bistórico en honor..., pp. 49 y 326-329, respectivamente.

36 Aquellos ingenieros que por el diario de Román sabemos que estuvieron en Nancy y Caudebec, la referencia más común al respecto es que "estuvieron en Francia” SALAS, Mariano: Obelisco histórico en honor..., (páginas entre paréntesis): Manuel Bayo (p. 130), Quintin de Velasco (p. 132), Juan Manuel de Quiroga (p. 134); Cayetano Zappino (p. 124); José Font (p. 124); y otros compañeros que se afrancesaron allí, como Manuel Caballero (pp. 127-128). Tales fueron los compañeros que aparecen en el diario de Román, por lo que es posible que tuvieran similar experiencia a la suya, aunque Salas no recogiera la referencia.

37 Mariano SALAS dice de José Cortínez que "Estuvo prisionero en Francia, de donde regresó en 1816", SALAS, Mariano: Obelisco histórico en honor..., p. 129. Cortínez también aparece en las referencias del diario de Román, y que hemos constatado que estuvo en Nancy y Caudebec, de donde no escapó, por lo que estuvo prisionero de 1809 a 1816.

38 AHN: Diversos-colecciones, n.71. Noticias sobre pasados y prisioneros franceses, canjes y juramentados durante el año 1813. Carta del marqués de Compigny al Sr. Intendente de este ejército y reino. Palma 2-VIII-1813. Tomado de: PELLISER, Pierre; PHELIPEAU, Jèrôme: Les grognards de Cabrera...

39 Así sucedió con el manuscrito que me encargaron editar, que no se sabe cómo llegó a los fondos de la Fundación Lázaro Galdiano (FLG): Diario del Yngeniero militar Don José María Román, desde que con sus compañeros de estudios salió de Alcalá de Henares la noche del 9 de junio de 1808, tomó parte de la defensa de Zaragoza durante los dos sitios; prisionero en el último, fue conducido al depósito de Nancy hasta su regreso a España en agosto de 1814. FLG: Manuscrito, Inventario: 11.352, M.7-2-19.
} 
privados como el aquí analizado para recomponer la experiencia de ese tipo de prisioneros medios en la época napoleónica ${ }^{40}$.

Tal fue precisamente la base que originó este estudio. Una fuente que había permanecido, junto a la idea de que era un diario singular pero que podía estar registrando de una experiencia colectiva más generalizada y ocultada ${ }^{41}$. Un diario personal escrito por un ingeniero entre 1808 y 1814. El diario sobrevivió a los dos sitios de Zaragoza, al cautiverio durante un lustro en Francia, y a las vicisitudes posteriores de la época ominosa Fernandina. Después, el manuscrito fue a parar a los fondos de la Fundación Lázaro Galdiano. Ésta, con motivo del bicentenario del levantamiento contra Napoleón, encargó su edición crítica a quien escribe estas páginas ${ }^{42}$. Así vio la luz el diario de José María Román, del que cada vez continúa investigando más facetas, entusiasmada por la interesante labor de ese ingeniero ${ }^{43}$, lo que se ha hecho extensible a su familia ${ }^{44}$ y a compañeros de aventuras militares ${ }^{45}$.

Dicho diario sirve aquí de eje para estudiar el cautiverio de los suboficiales que fueron conducidos prisioneros a Francia tras la derrota del segundo sitio de Zaragoza, en febrero de 1809. La experiencia puede ser representativa de parte de los miles de prisioneros que permanecieron en Francia. Estos oscilan entre cincuenta mil -según Aymes- y cien mil -según Menéndez Pidal ${ }^{46}$-, cifras dudosas ya en la época incluso ante los propios cálculos de los capitanes generales y otros que dejaron registro ${ }^{47}$. En principio, sólo

\footnotetext{
40 Aunque existen, no abundan las memorias escritas entre 1808 y 1814 que recojan este tipo de experiencias, que gracias al fenómeno del bicentenário han salido a la luz o se han reeditado y traducido. Como la que plasma el cautiverio hacinados en el buque "El terrible": BLAZE, Sébastien (trad. MORENO, Mariano; introd. MORENO, Manuel), Memorias de un boticario. Episodios de la Guerra de la Independencia, Biblioteca Histórica, Sevilla, 2008. Buen ejemplo del uso de estas fuentes privadas lo hace para el caso de los 12.000 prisioneros en Escocia: MAC-DOUGALL, Ian: All Men Are Bretbren ..., pp. 9-15.

${ }^{41}$ Sería el tipo de fuentes que podrían catalogar los fenómenos de "lo excepcional normal" definido por Carlo Ginzburg en sus análisis de Micro Historia. Referiré la obra que compendia una reflexión en relación com otras obras: PONS, Anaclet; SERNA, Justo: Cómo se escribe la MicroHistoria, Ensayo sobre Carlo Ginzburg, Barcelona, Cátedra, 2000, pp. 99, 259 y siguientes.

${ }^{42}$ ZOZAYA, María: «Novecientas Leguas», en: ZOZAYA, María; ROMÁN, José Ma: Viaje y prisión del ingeniero militar José María Román, Madrid, FLG, 2008, p. 1-32.

${ }^{43}$ ZOZAYA, María: "Prisionero en libertad. Vivencia de un ingeniero militar deportado durante la Guerra de la Independencia", en: CARO, Diego; DURÁN, Fernando (Coords.), Experiencia y memoria de la revolución española, Cádiz, Universidad de Cádiz, 2011, pp. 173-192.

${ }_{44}$ ZOZAYA, María: "Qui est Blake? Une biographie, deux personnes, quatre mains". Poster, Congreso internacional Temporalité et Contextes, UCM, Madrid, 11-V-2012.

${ }^{45}$ ZOZAYA, María: "Reflet de la prison. Mémoires d'une captivité en France (1808-1814)", en: Construcció $i$ projecció de la memòria personal a l'Ėpoca Moderna, Barcelona, Institut d'Estudis Catalans-UAB, 2011. Sobre las buenas relaciones con el vecino francés: ZOZAYA, María: «Враг и граница: изменения образа «Аругого». («L'ennemi et la frontière : transformation de l'image de «l'autre »), Annuaire d'études françaises, "La campagne russe" de Napoléon, événements, images, mémoire, L'image de l'ennemi dans les guerres napoleoniennes: propagande, perception, memoire Russian Accademy, Moscow, 2013; pp. 115-126.

${ }^{46}$ AYMES, Jean-René: La deportación bajo el Primer Imperio, ...

${ }^{47}$ Como puede verse en las cartas de Blake, publicadas en: BENAVIDES, Nicolás; YAQUE, José A.: El Capitán General don Joaquin Blake...
} 
desde Zaragoza salieron más de diez mil prisioneros civiles y militares para Francia ${ }^{48}$. Román calculaba que en la Caserna de Santa Catarina que les alojó inicialmente en Nancy, podía haber entonces unos tres mil hombres. Si bien los números concretos sólo podrán salir a la luz con estudios posteriores, es el plano cualitativo lo que más interesa reconstruir aquí.

\section{DEL OFICIO DE LA GUERRA AL CAUTIVERIO DE GUERRA}

El autor del manuscrito que es la fuente principal de este estudio es el ingeniero militar José María Román. Dicho vallisoletano cursó sus estudios en la escuela de Zamora ${ }^{49}$. En aquella altura la carrera de ingeniería militar estaba siendo modificada en España. A finales del siglo XVIII, diversas escuelas de especializadas en diversos ramos de la ingeniería estaban dispersas por toda España. Fueron unificadas en la Real Academia de Ingenieros Militares de Alcalá de Henares al comenzar el siglo XIX ${ }^{50}$. A ese lugar próximo a Madrid se trasladó Román, donde se licenció como ingeniero en $1804^{51}$. Tres años después, pasó a ser profesor de la Academia junto con otros compañeros de su promoción. Con ellos y otros profesores iba a compartir las aventuras de guerra y cautiverio en Francia. Entre sus colegas se encontraban personajes que después alcanzaron cierta relevancia, dado que destacaron entre los cuerpos de élite de la ingeniería y en el servicio al Estado. Tales fueron el coronel Manuel Pueyo Díez, el sargento Mayor Antonio Sanguenís Torres, el capitán Julián Albo Helguero, el teniente Luis Landabúru, el capitán Francisco Bustamante, y otros dos que pasados los años iban a ser diputados: el capitán Cayetano Zappino y el teniente José Cortines Espinosa, condecorado más tarde -aparente paradoja por haber sido años atrás su prisionero- con la Legión de Honor francesa ${ }^{52}$.

A raíz del levantamiento de mayo de 1808 en Madrid, estalló el movimiento de resistencia contra el francés. Hicieron lo propio los profesores de la Real Academia de ingenieros: cerraron su actividad en las aulas y partieron en diversas expediciones acompañados de alumnos. Se dirigieron tanto hacia Valencia como a Zaragoza con el

\footnotetext{
48 GARCÍA M., Fernando: Memorias para la historia militar de la guerra, Madrid, s.n., 1817, pp. 156-158.

49 Archivo General Militar de Segovia: Secc. 1a , Leg. R. 2757, fol. 5. Archivo Histórico Nacional: Consejos, 12138, Exp. 12.

${ }^{50}$ Los cambios y evolución de las escuelas en: CAPEL, Horacio; SÁNCHEZ, Juan E.; MONCADA, Omar: De Palas a Minerva, Madrid, CSIC, 1988, pp. 207-215.

${ }^{51}$ Román fue el número 55 de las listas de la primera promoción de alumnos de ingeniería. Real Academia de Ingenieros: Memorial del Arma de Ingenieros, abril 1911, LXVI, no IV, T. 66, pp. 329-331.

52 ZOZAYA, María: “José Cortines Espinosa”, en: Diccionario biográfico de parlamentarios españoles. 1820-1854, Madrid, Cortes Generales, 2012. Documento que agradezco que encontrase Odile Bouchut (CDN).
} 
objeto de preparar las ciudades para la defensa y el ataque de los ejércitos napoleónicos. En junio de 1808, con el comienzo de la expedición, se iniciaba el diario de José María Román.

En cada proceso bélico los ingenieros debían llevar un cuaderno de campo como parte de su trabajo. En estilo breve, austero y muy concreto, se centraba en los puntos de estrategia de guerra y aprovisionamiento. Si bien cuando variaba la situación, solía tornarse en un escrito de naturaleza antropológica ${ }^{53}$. A partir del momento cuando el grupo de ingenieros fueron cogidos prisioneros, el manuscrito de Román fue cambiando: de hablar de estrategias de guerra pasó a relatar la penosa experiencia del comienzo del sometimiento al francés, que fue duro en los inicios, como veremos. Román y sus compañeros se contaban entre los más de diez mil prisioneros civiles y militares que desde Zaragoza tomaron rumbo a tierras galas bajo el imperio napoleónico. Algunos se escaparon, otros murieron y a otros los mataron en el camino. En 1809 les condujeron a Nancy, situada en la Lorena francesa, a principios de 1814 los condujeron a Caudebec, en la Normandía. Cuando Román y sus compañeros más cercanos huyeron de allí, finalizaron su cautiverio, si bien otros no corrieron la misma suerte y siguieron las órdenes de marchar con el regimiento hacia el norte, a Caen, donde continuaron prisioneros hasta 1816.

El cautiverio de Román duró "cinco años, dos meses y quince días" ${ }^{54}$, como él mismo registró en su cuaderno. A mi juicio, en esa expresión reproducía el modelo del expediente personal -en su caso, militar- donde era común que figurasen ese tipo de cómputos de los servicios realizados. Es plausible que el empleo de ese patrón de cálculo indique que el ingeniero Román -y quienes lo usasen igual-, concibió ese tiempo de desplazamiento y cautiverio como un tiempo dedicado al servicio militar para el Estado. Es decir, como años en que al ser prisionero eran conmensurables como parte de sus obligaciones de la lucha por la patria, como en efecto le fue reconocido después.

\section{CAUTIVOS DEL FRANCÉS. LOS MOMENTOS INICIALES DE DESPLAZAMIENTO}

Una vez prisioneros los ingenieros militares, comenzaron su desplazamiento a Francia bajo la custodia de los soldados napoleónicos. Como sucedía en casos equivalentes, los suboficiales de ingeniería y de las armas eran considerados prisioneros de élite. Sus condiciones de vida se regulaban por estatutos que les igualaban a los propios militares

53 CAPEL, Horacio: "Los Ingenieros Militares y su actuación en Canarias", en: Actuación de los ingenieros militares en Canarias, S.XVI-XX, Cátedra General Gutiérrez, Tenerife, 2001, pp. 13-54.

${ }^{54}$ ZOZAYA, María; ROMÁN, José $\mathrm{M}^{\mathrm{a}}$ : Viaje y prisión del ingeniero militar... 
franceses de su rango ${ }^{55}$. Era normal que recibiesen un tratamiento especial en el país vecino, manteniendo los códigos de honor de los grupos privilegiados dedicados a las armas, al estilo del siglo XVIII ${ }^{56}$. De ese modo, pese a tener el rango de prisioneros, percibían un sueldo y se mantenían bajo el juramento de palabra. En los confines de la ciudad prisión, no estaban concentrados en un espacio común cerrado, ni recluidos al estilo de las cárceles contemporáneas, como erróneamente pueda concebirse transfigurando aquella realidad ${ }^{57}$.

Los momentos iniciales sí que pueden vincularse al trato negativo, pues fueron muy duras las condiciones de los primeros momentos de la capitulación y del desplazamiento inicial. Tras ser detenidos los ingenieros en Zaragoza, pasaron una de las peores noches de todo el tiempo de guerra. Los soldados de Napoleón les condujeron a un corralón junto a la Casa Blanca, no les dieron nada para comer ni leña para calentarse, pese a que "el frío era expresivo" 58 . Los prisioneros sufrieron en principio el trato vengativo del ejército francés, como fusilamientos al azar y por cansancio, robos de armas de valor y otros $^{59}$. Además de ese trato brutal, es probable que la percepción negativa aumentase por el hecho de que los franceses incumplieran varias condiciones de la capitulación propias de los grupos de élite ${ }^{60}$.

De manera paulatina fueron mejorando la situación. En el trayecto en España durmieron en variados lugares, que iban desde un corral hasta una universidad ${ }^{61}$. Román logró parar en casi todas las etapas en casas de particulares. En Caparroso, merindad navarra de Olite, se alojó con dos compañeros en casa del escribano, quien les dio una buena cena y cama "que no habían disfrutado en todo el sitio" de Zaragoza ${ }^{62}$. Ya durante la

\footnotetext{
55 CLIMACO, Cristina; Carlos GUARDADO: «Prisioneiros portugueses em França ..., pp. 337-340; 344.

56 Sobre las formas de cautiverio en la Edad Moderna -que directamente se emplean en la época de 1808-, véase el caso estudiado por: MARTÍNEZ-RADIO, Evaristo: "Campesinos y cautivos en la Guerra de Sucesión y el ejemplo “de Almansa a Asturias”, en PÉREZ, M José; RUBIO, Laureano M. (eds.): Campo y campesinos en la España Moderna, León, FEHM, 2012, T. II. Asimismo: "Prisioneros de guerra en el siglo XVIII. Formas, usos, derechos y deberes del cautivo", La Guerra de Sucesión y Asturias, Oviedo, Principado de Asturias, 2009, pp. 267-273.

${ }^{57}$ Precisamente por realizar comparaciones para que el lector se haga a la idea, el propio Aymes señala que los depósitos donde fueron conducidos muchos prisioneros a Francia, que agrupaban a suboficiales y soldados rasos, "prefiguran los campos de concentración del siglo XX". AYMES, Jean-René: La Guerra de la Independencia en España. Calas y Ensayos, Madrid, CSIC-12 Calles, 2009, p. 464.

58 ZOZAYA, María; ROMÁN, José Ma: Viaje y prisión del ingeniero..., p. 57.

59 También sucedió eso con prisioneros franceses en cárceles y barcos cárcel británicos: DALY, Gavin: "Napoleon's lost regions..., pp. 373-375.

${ }^{60}$ Registró los incumplimientos tras la derrota: GARCÍA M., Fernando: Memorias para la historia militar de la guerra, Madrid, s.n., 1817, pp. 156-158.

61 Otros aspectos de los objetos personales, las armas, la comida a la vida cotidiana del mismo que ocupa estas páginas: ZOZAYA, María: “Armas, ropas, comidas y casernas. Vida cotidiana de un ingeniero militar en tiempo de guerra y prisión”, en: Jiménez Estrella, A; Lozano, Julián J. Conflictividad y violencia en la Edad Moderna, Granada, Universidad -FEHM, 2012, pp. 1253-1268.

${ }^{62}$ ZOZAYA, María; ROMÁN, José Má: Viaje y prisión del ingeniero..., p. 58.
} 
marcha en Francia hacia el depósito de Nancy, les alojaron en casernas militares, hospitales, casas particulares y otros.

Cuando estaban destinados a una caserna, podían ir a ella a pasar lista de día pero a dormir por la noche en las casas de particulares, era la ciudad por cárcel propia de etapas anteriores $^{63}$. Este sistema bien podría haber sido fuente de inspiración del denominado "iluminismo penal" ${ }^{64}$, y era común para los cuerpos de élite militar, pues se trataba de prisioneros privilegiados. Estaban allí "bajo palabra" de no escaparse, como en el resto de la Europa Moderna ${ }^{65}$. Pero ese régimen también se debía a los medios con que contaban en la época para alojar a los detenidos, pues las prisiones de fortaleza sólo se encontraban en ciertas plazas; además, una guerra suponía una situación extraordinaria donde se conducía a un gran contingente humano hacia una población, y tales situaciones tenían que salvarse a menudo improvisando otros alojamientos, como los que siguen a continuación.

\section{LAS FONDAS POR LAS QUE PASARON COMO PRISIONEROS EN FRANCIA}

Durante el camino, una vez que como prisioneros pasaron a territorio francés, los suboficiales residieron en fondillas y posadas (en el diario se mencionan los compañeros profesores de la Real Academia de Ingenieros). José María Román destacaba su elevada calidad, que no variaba por pequeños que fuesen los pueblos; y su cantidad, pues señalaba cómo se contaban una infinidad de posadas en todas las carreteras. Afirmaba que "hasta en el lugar más infeliz hay tres o quatro y, en todas, unas camas muy buenas y quartos muy decentes" "66. Las habitaciones de alquiler eran chambres garnies, cuyo precio variaba desde seis y ocho francos hasta treinta o treinta y seis al mes, lo cual dependía del lugar y del piso en donde se hallase cada cual, de su tamaño y de los adornos con que contase.

En ese ámbito de las condiciones de vida cotidianas, durante la estancia de cinco años de los ingenieros, Román registró diversas formas de calentarse en Francia. Lo más común era que templasen los aposentos con estufas o fogatas en chimeneas. En la caserna militar que luego veremos, utilizaron éstas últimas, como además puede observarse por las chimeneas de sus tejados que aparecen en las postales (Imágenes 2, 3 y 4). Respecto a las habitaciones de alquiler, Román relataba que cada cuarto tenía una chimenea con su repisa

\footnotetext{
63 Trata los pormenores de este tipo de prisión: ORTEGO, Pedro: "La ciudad por cárcel”, I congreso internacional sobre Historia de la Prisión, Ciudad Real, U-CM, 2013.

64 PELAYO, Ángel: "La humanización el proceso penal y procesal. Razón y sensibilidad”, Derechos y Libertades, 4, n.7 (1999), pp. 253-254.

${ }^{65}$ DALY, Gavin: “Napoleon’s lost regions..., p. 364-365. MARTÍNEZ-RADIO, Evaristo: "Prisioneros de guerra en el siglo XVIII"..., pp. 267-273.

66 Más condiciones de vida en: ZOZAYA, María: “Armas, ropas, comidas..., pp. 1260-1261.
} 
de mármol, en la cual a veces se metía una chimenea turca de hierro "de la qual el fuego se aproxima un poco a lo interior del aposento”. Señalaba que lo más efectivo para calentar era la estufa, que daba el mismo calor con menos leña; que el material y las cualidades podían variar mucho. Existían estufas de hierro fundido, de hierro en hojas (tôle), o de barro (de fayence), las cuales, aseveraba, "no ofenden la cabeza y procuran un calor muy dulce ${ }^{, 67}$. En tiendas y otros espacios donde no existían medios mayores, las mujeres empleaban el couvet, que era "un maridete o puchero de barro o de cobre" que se colocaba "debajo de las sayas, con fuego", en el cual "las señoras finas" usaban una rejilla para poner los pies sobre aquel artilugio, que en este caso se convertía en un diferenciador social ${ }^{68}$ al que no parecían tener acceso los prisioneros.

\section{EL CAUTIVERIO EN LA CASERNA DE SANTA CATALINA O THIRY, EN NANCY}

El 19 de abril de 1809 llegaron todos los prisioneros a su destino inicial del depósito de la ciudad de Nancy. Pasaron a su caserna militar principal, la más destacada de las varias que contaba la ciudad. Se trataba de la caserna de Sainte Catherine, que en el 1800 estuvo junto a la puerta del mismo nombre. Posteriormente iba a pasar a llamarse Caserne Thiry ${ }^{69}$, de la que se han conservado cartas postales y fotografías de 1900 (donde nunca aparece registrado aquel primer nombre $)^{70}$. Además, desconocíamos que tales instantáneas se correspondiesen con el interior de la caserna que aquí concierne porque en algunas sólo figuraba el nombre de 69 Régiment, en vez del nombre de la Caserne Thiry. Por ello, no sabíamos que estuvieran referidas al mismo lugar ${ }^{71}$ y aquí las ofrecemos para contrastar con imágenes el espacio descrito por Román, y que acogió el cautiverio de esos ingenieros.

La caserna Thiry albergó al regimiento Sesenta y nueve de infantería francés (69 Régiment). Así lo he podido comprobar por una de las imágenes de las postales (Imagen 3) en donde aparece el nombre de dicho regimiento junto con la imagen de la caserna Thiry. Ese dato me permitió saber que allí se alojó un regimiento que participó en todas las campañas importantes de la Revolución Francesa y el Imperio de 1769 a 1815. Además,

\footnotetext{
${ }^{67}$ ZOZAYA, María; ROMÁN, José Má : Viaje y prisión del ingeniero..., p. 82.

68 ZOZAYA, María; ROMÁN, José Má: Ibidem, p. 108.

${ }^{69}$ CHARVET, M. Leon (dir): Réunion des sociétés des beaux-arts des départements (1897-1906). Table analytique et raisonnée des comptes rendus des sessions des sociétés des beaux-arts, Ministère de l'instruction publique de France, Paris, Plon Nourrit, 1909, p. 334.

70 Agradezco enormemente a Odile Bouchut (CDN) que me facilitara estas imágenes de Nancy, publicadas en: http://www.als.uhp-nancy.fr/digicode/111.html, que proceden del fondo de la colección privada de Pierre Boyer, como se cita a pie de cada foto.

${ }^{71}$ Otras dos imágenes complementarias en: ZOZAYA, María: “Armas, ropas, comidas..., pp. 1266-1268.
} 
gracias a que figuraba el mismo nombre de 69 Régiment, pude localizar otras postales que contenían diferentes partes internas de la caserna. Desconocía que perteneciesen al mismo conjunto, lo que es de gran relevancia para alumbrar sobre la forma de vida cotidiana en la caserna (Imágenes 5, 6 y 7).

La estética de esta caserna es una cuestión destacable. En otro trabajo asimilé esta caserna a las propias de la época. A la idea de que los edificios empleados y construidos como caserna reproducían los modelos de edificios de reclusión, de construcción severa, funcional y monumental ${ }^{72}$ propios de lugares militarizados y de frontera (aunque -como luego veremos- esta caserna era algo más). Así puede parecer cuando se leen las primeras descripciones que de este edificio hizo Román: “Al extremo de la calle de Santa Catalina se halla la caserna, compuesta de tres edificios que forman los tres lados de un rectángulo". "La caserna del medio es más larga que las de los lados. En quanto a las demás, son enteramente iguales" ${ }^{, 73}$. En efecto, así se comprueba al ver las postales de la caserna de 1900 (Imagen 2). Respecto a sus límites, Román señalaba: su "cuarto lado está formado por un foso y una barandilla, y en medio del qual está la puerta" ${ }^{, 74}$. En las fotos se contempla cómo el foso y la barandilla se sustituyeron un siglo después por una gran reja (Imágenes 4 y 9), más propia de las estructuras contemporáneas que el antiguo foso de la defensa estilo medieval. Román iba a incidir en el perfil del mundo castrense al señalar su funcionalidad: "Esta plaza sirve para las evoluciones e instrucción de las tropas" 75, lo cual puede quedar ilustrado en la imagen donde los soldados aparecen formando en el patio un siglo después (Imagen 2).

Asimismo, es importante la descripción de las estancias donde los desplazados de guerra iban a residir durante los primeros meses. Román señalaba respecto al interior de la caserna: "Cada una de ellas tiene quatro pisos, sin contar las bodegas ni desvanes, que son muy considerables. Estas casernas están interiormente divididas en cuartos iguales (Imagen 4). En todos ellos hay chimenea y cada uno contiene seis camas anchas y, por consiguiente, según el uso de Francia, hay alojados doce soldados. Los pabellones de los oficiales son enteramente iguales a los otros quartos en quanto a la magnitud, pero están divididos interiormente en tres partes". Calculaba que en el cuartel podía haber entonces unos tres mil hombres. Ya desde 1811 se sabía que ese cuartel real tenía capacidad para alojar hasta

\footnotetext{
72 SALA, Teresa M. : La vida cotidiana en la Barcelona de 1900, Madrid, Sílex, 2005, p. 160. No sucedió así en Caudebec, ciudad donde se iban a alojar en 1814, carente de instalaciones militares equivalentes.

${ }^{73}$ ZOZAYA, María; ROMÁN, José Ma: Viaje y prisión del ingeniero..., p. 70.

${ }^{74}$ ZOZAYA, María; ROMÁN, José Ma': Ibidem, p. 70.

75 ZOZAYA, María; ROMÁN, José Ma: Ibidem, p. 70.
} 
cuatro batallones de infantería, como fue usado conforme avanzó la centuria ${ }^{76}$. Es probable que fueran sólo los prisioneros de la guerra de España quienes la habitaban, al igual que las otras tres casernas de Nancy. También es probable que, al igual que los prisioneros portugueses en Francia, esas casernas fueran diferenciadas según las clases, para los soldados y para los oficiales ${ }^{77}$.

El ingeniero describió más elementos de su disposición: “A las dos extremidades de la caserna del fondo hay dos fuentes abundantes" ${ }^{\text {78 }}$. Una de ellas puede observarse en las postales de las instalaciones (Imagen 5). Tal vez algo modificada un siglo después, en 1900, una de las fuentes aparece cumpliendo también la función de lavadero. Es posible que ya lo fuese en 1810, y que desempeñase además labores polivalentes como lugar de encuentro y sociabilidad improvisada entre los cautivos ${ }^{79}$.

José María Román proseguía describiendo otras partes que no habíamos logrado saber que pertenecían a la misma estructura de la Caserne de Sante Catherine, cuyas representaciones postales podemos contemplar (Imagen 6). En concreto, cuando dice: “más lejos, en los dos ángulos de una tapia que rodea todos estos edificios, están colocados los comunes. Además de este quartel hay otros tres mucho menos considerables; uno de ellos sirve para caballería" ${ }^{\prime 0}$. Pueden observarse los comunes, probablemente ubicados en el mismo lugar -aunque después tuviesen cambios internos- donde los describía Román, acompañados ya de otro edificio que era la enfermería en 1900 (Imagen 6).

En la configuración de las instalaciones de la Caserne Thiry cabe señalar que, al menos a la altura de 1900, había una cantina que se denominaba "Le cocq" (Imagen 7) ${ }^{81}$. "El gallo" implicaba un término referido a un icono que con frecuencia se vinculó a la representación del pueblo en la Revolución Francesa, que Napoleón sustituyó por el águila imperial y luego volvió a restituirse desde $1830^{82}$. Con este u otro nombre, es muy posible que la cantina se ubicase ahí desde sus inicios, sirviendo como lugar de abastos y encuentro entre los reclusos. Sería uno de los múltiples espacios de sociabilidad castrense donde se

\footnotetext{
${ }^{76}$ LIONNOIS, J. J.: Histoire des villes vielle et neuve de Nancy, depuis leur fondation jusqu'en 1788, Nancy, Haener Pére, 1811, T. II, p. 188. ZOZAYA, María; ROMÁN, José Ma: Viaje y prisión del ingeniero..., p. 70.

${ }_{77}$ CLIMACO, Cristin; GUARDADO, Carlos: «Prisioneiros portugueses em França..., pp. 338-339.

78 ZOZAYA, María; ROMÁN, José Mª : Viaje y prisión del ingeniero..., p. 70.

${ }^{79}$ Aunque no siempre tuviera que ser pacífica, como acontecía en conflictos generados en la época entre las mujeres cuando realizaban estas tareas. RISCO, Antonio: "Espacio, sociabilidad y control social. La superintendencia general de policía para Madrid y su rastro (1782-1808)". MADRAZO, Santos (ed.): Madrid en la época moderna: espacio, sociedad y cultura, Madrid, Casa de Velázquez, p. 111 (pp. 97-127).

80 ZOZAYA, María; ROMÁN, José Ma: Viaje y prisión del ingeniero..., p. 70.

81 Dato que sabemos gracias a la nota de la postal que anunciaba que la caserna Thiry albergaba el 69 regimiento de infantería. Si bien el gallo en la actualidad se escribe "coq", esta era una forma contemplada antiguamente.

${ }^{82}$ Sobre todas las cuestiones simbólicas, remito a AGULHON, Maurice: 1848 ou l'apprentissage de la République, 1848-1852, Paris, Seuil, 1987.
} 
podían establecer múltiples redes sociales y fenómenos de relación a partir de la mesa ${ }^{83}$. Lazos cotidianos que, se reprodujesen tanto en el interior de la caserna como en sus entornos inmediatos, resultan muy difíciles de recomponer, salvo que se encuentren similares fuentes de naturaleza privada que esperemos salgan a la luz en futuros estudios.

De cualquier modo, toda esa descripción sobria inicial de Román de carácter militar, es posible que se correspondiese poco con lo que esa caserna representaba en Nancy. Es decir, su alcance simbólico en la ciudad era mucho mayor que el del mero edificio militar que relata este ingeniero. El diseño fue realizado por el prestigioso Richard Mique, director general de las obras del rey de Polonia Stanislas, gran duque de la Lorena y luego rey de Nancy, a quien estaba dedicada la caserna. Se puso su primera piedra en 1764, y en 1766 Nancy pasaba a pertenecer a Francia, cuando moría el Rey Stanislas sin ver finalizado el edificio. Se llamó también Cuartel Real, y era de estilo neoclásico puro, por lo que su estética representaba el orden, con la línea perfecta y el trazado cuadrangular. Costó más de 500.000 francos, cantidad conseguida con impuestos que desmantelaron a media región. El objetivo del edificio era resaltar la munificencia y grandeza del rey Stanislas, a quien se representó en bajo relieve con diversos atributos en el frontón del cuerpo principal. El conjunto resulta mucho mejor que cualquiera de las otras casernas de Nancy, que si bien confirman su estructura urbana como una plaza militar, la permiten destacar en el plano artístico (Imagen 3).

Llama la atención que, con la dedicación que José María Román prestó en otras partes del diario a describir el paisaje urbano, aquí no hiciese concesión alguna al elemento artístico arquitectónico. Su descripción puede asimilarse al retrato que de la caserna realizó Emile Bégin más de 20 años después. En su guía de Nancy afirmaba: "Les casernes de SainteCatherine, appelées aussi Quartier Royal, élevées près de la porte, présentent trois corps de bâtiment construits autour d'une place, ayant environ cent toises de largeur sur une profondeur de quatre- vingts ${ }^{\prime 4}$. Tras esa descripción casi académica de los tres cuerpos del Edificio Real en torno a la plaza, Bégin si hacía una relevante concesión estética del edificio, afirmando que era "d'un genre élégant et sévère", y que era "Inutile d'ajouter que peu de casernes en Europe sont comparables á celles de Sainte Catherine" 85 . Esto es, se trataba de un edificio de arquitectura severa y elegante al que muy pocas casernas podían compararse en toda Europa. En la misma línea de resaltar las cualidades de este conjunto

\footnotetext{
${ }^{83}$ LE GOFF, Jacques: La Sociabilité à table, Rouen, Université de Rouen, 1992. En la prisión aborda algunos: BARROSO, Ana M.: Redes de sociabilidade numa prisão..., pp. 55 y ss.

${ }^{84}$ Emile A. N. J. Bégin, Guide de l'étranger à Nancy, Legrand, Paris, 1835, p. 174.

${ }^{85}$ Emile A. N. J. Bégin, Ibidem..., p. 174.
} 
de edificios, otros escritos de la época la señalaban como uno de los edificios militares más remarcables por su belleza ${ }^{86}$.

En el caso de las descripciones de la caserna de José María Román, llama poderosamente la atención el hecho de no subrayar tales virtudes, cuando sin embargo era ferviente admirador del neoclasicismo arquitectónico, como refirió de manera continuada en su diario, por su orden y trazado perfecto (Imagen 3). A mi juicio, que pasase este detalle por alto se debió al condicionante de la derrota, el desplazamiento y que fuera su toma de contacto inicial. Considero que fue una reacción ante la idea del depósito en los momentos iniciales de la llegada, por enfrentarse desde un plano psicológico a la medida del cautiverio y a la idea de ser prisionero en esa caserna. Esa percepción es probable que se pudiera hacer extensible a más de sus compañeros ingenieros. Este ámbito entra dentro del campo de las vivencias, que iban a cambiar en muchos aspectos conforme se prolongase la estancia, como veremos a continuación.

\section{RIGUROSIDAD EN LOS CONTROLES, ¿UNA CUESTIÓN DE ARBITRARIEDAD PERSONAL?}

Los ingenieros estuvieron en la caserna de Sante Catherine desde abril de 1809. Ya desde junio algunos como Román empezaron a residir en casas particulares bajo palabra de no escaparse. El régimen de control fue variando según la época. Los registros parecen indicar que la rigurosidad en la vigilancia de los prisioneros dependía de decisiones y motivos de carácter personal. Primero, tanto el buen trato como, por el contrario, la severidad cuando se aplicaban normas muy rígidas, dependían de la decisión arbitraria del mandatario superior. Segundo, a la par, esos mismos controladores iban a ejercer selectivamente tratos preferentes con sus prisioneros, y a establecer un comportamiento diferenciado, como también se ha señalado en otros casos de la época ${ }^{87}$.

En 1809, los ingenieros prisioneros españoles comenzaron su estancia con el comandante Morot. José María Román apuntaba que, pese a robarles algo de su haber, "era hombre bueno"88. Lo mismo iba a repetir después sobre quien le siguió en el cargo, el general Gilot. Con ellos la vigilancia fue muy laxa. Respecto a la periodicidad para el

\footnotetext{
86 JOUBERT, M. Louis: "La jeunesse du doyen, nouvelle", Le correspondant, Recueil Periodique, Paris, Douniol, 1864 , p. 566.

${ }^{87}$ Señala la arbitrariedad en función de las personas y las diferencias según las cárceles de la época para el caso británico: DALY, Gavin: “Napoleon’s lost regions: ..., pp. 372-375.

${ }^{88}$ Esta situación relativamente positiva del diario de Román ya fue publicada en un breve texto en que reproducía literalmente extractos de su diario: ACEBAL, Francisco López: La lectura, revista de ciencias y de artes, Vol. 11, parte 2, 1908, p. 334.
} 
control, apenas tenían que pasar lista en la caserna una vez al mes. Había una flexibilidad de horarios. Tampoco les fijaban ninguna hora concreta de recogida nocturna y les era permitido andar hasta cualquier hora de la noche. En cuanto al espacio, no tenían límite de movimientos. No les circunscribieron la distancia a la que debían salir fuera de la ciudad, por lo que se iban incluso a las romerías y fiestas de los pueblos vecinos ${ }^{89}$. Pudieron disfrutar de la sociabilidad tradicional festiva de la zona sin límite. Tan bueno fue el trato en ese periodo de prisión que Román lo consignó como un "tiempo de libertad”, aparente paradoja que ya he analizado en otro estudio ${ }^{90}$. En principio, es identificar tal situación con una vivencia propia del cautiverio ni con la imagen clásica del prisionero de guerra.

Para equilibrar el fiel de la balanza y no ir al lado radicalmente positivo de la prisión, voy a introducir otras claves. En este caso, la relación psicológica positiva con la prisión es probable que también pueda vincularse al nivel de aceptación y asunción de las normas del cautiverio. Podríamos categorizarlo como la "prisionalización" que definió el doctor Clemmer, para referirse al fenómeno según el cual el recluso asume las normas y valores que rigen la prisión ${ }^{91}$. Tal interiorización de ese régimen, en que se acepta la privación temporal de libertad -frente a los reclusos que no la aceptan- me permite establecer un pequeño paralelo para contrastar dos visiones posteriores de dos soldados que estuvieron en la misma caserna de Santa Catherina, después denominada Thiry. Voy a servirme de ese paralelo para alumbrar sobre las condiciones de vida de los cautivos, en concreto para acercarme al fenómeno de la percepción de la estancia en la caserna, para constatar el elevado papel que tenía la vivencia negativa o positiva por parte del cautivo.

Es interesante sacar a colación el ejemplo para mostrar que, ni todos los soldados y suboficiales podían hablar como Román respecto a los aspectos positivos de esa prisión de élite, ni tampoco todo el tiempo en que vivió el cautiverio el propio ingeniero militar consideró igual el régimen de la caserna. La base de las imágenes que empleo procede de nuevo de la colección privada del coleccionista Pierre Boyer, de su amplio fondo sobre Nancy. Se trata de dos postales de 1900, muy similares (Imágenes 8 y 9), en donde aparece la caserna donde residieron los desplazados en el 1800. Pero, sin embargo, tales imágenes parecidas dejan entrever dos actitudes muy diversas hacia ese mismo espacio de reclusión. Empleo la palabra reclusión porque en 1900 era un momento en que la caserna ya no actuaba en puridad como un espacio de prisión, sino como cuartel del servicio militar francés.

${ }^{89}$ ZOZAYA, María; ROMÁN, José Má Viaje y prisión del ingeniero..., p. 103.

90 ZOZAYA, María: "Prisionero en libertad"..., pp. 173-192.

${ }^{91}$ Referencia tomada de: BARROSO, Ana M.: Redes de sociabilidade numa prisão..., p. 39. 
En la primera postal aparece un soldado haciendo el saludo militar o de visera (Imagen 8), junto a un cuadro donde se representa la entrada de la caserna, en cuyo marco cuelga una banda con la bandera francesa atada a una hoja de palma. Al llegar el siglo XX, fueron comunes estas postales de evocación amable donde diferentes elementos militares se vinculaban a los símbolos de la nación. A mi juicio, representa de esa manera pacífica una relación de acomodo hacia el mundo del servicio militar. Por extensión, ésta caserna puede estar representando alegóricamente la aceptación del orden a través del servicio a la patria por la vía de las armas. En la segunda postal (Imagen 9) aparece dibujado un militar, cuyas las letras manuscritas que lo acompañan no expresan la misma filosofía. Al transcribir el texto en el margen, se lee: "Souvenir de la Caserne que je quitte sans regrets. On liquide et on s'en va. Henri" "l'heure de la délivrance ásomé pour (ilegible, ilegible). Es decir, el autor escribía: "Recuerdo de la caserna que dejo sin pesar ninguno. Rematamos y nos vamos. Henri" ${ }^{92}$. Y en el lateral incide en la marcha sin añoranza; más bien representa un momento de emancipación, cuando dice: "La hora de la libertad asoma por (ilegible, ilegible)". Un estado anímico de este semblante puede encontrarse o leerse entre líneas en el diario de Román cuando en la caserna pasaron a recrudecer las condiciones de vigilancia, como ahora veremos.

\section{EL CONTROL DE LOS DESPLAZADOS, VIGILANCIAS Y ESCAPISMOS}

El tipo de actitud de la primera postal (Imagen 8) podría identificarse, en el caso del ingeniero Román, más con los años iniciales. Dependiera o no del fenómeno de la "prisionalización", afrontaron esa primera etapa del cautiverio con una actitud optimista,

probablemente debida a varios motivos. Primero, a la comparación inmediata con las condiciones de guerra y del desplazamiento. Segundo, a la faceta de las relaciones personales que establecieron allí. La visión positiva pudo deberse a las buenas relaciones que luego abordaremos- compaginadas con el ámbito de sociabilidad intelectual que formaron y tejieron con el mundo universitario y de la academia. Los ingenieros, que eran un cuerpo muy cualificado, siguieron formándose aprovechando esa oportunidad que les brindaban las instituciones francesas. Fue común encontrarles en el Liceo o en la Biblioteca Pública de Nancy. Similares prácticas de formación intelectual se han interpretado en otros

\footnotetext{
${ }^{92}$ Transcripción y traducción propia de María ZOZAYA.
} 
casos como una manera de evadirse de esa realidad, como un tiempo psicológico construido por el cautivo que intenta superar la frontera física de sentirse prisionero ${ }^{93}$.

Con posterioridad, empeoraron las condiciones. En un momento dado endurecieron el régimen de cautiverio de los prisioneros por orden de los mandos superiores, debido a que las deserciones aumentaron. Comenzaron a cercenar la antigua libertad de horarios, la distancia y el tipo de movimientos que podían realizar. Pasaban listas dos veces al día, estableciendo un estricto control, censura de correspondencia y castigos por los cuales algunos fueron encerrados en castillos, pena mucho más cruda y temida ${ }^{94}$. Aumentaron la frecuencia de pasar las listas y redujeron las horas en que debían confinarse a los respectivos lugares donde residían. Román señalaba al respecto que ya en el tiempo de Gilot comenzaron a tener listas cada ocho días, se les prohibió salir de casa pasadas las diez de la noche, y los gendarmes asistían a las listas para hacerles formar. Y se les puso una lista diaria una vez que se escaparon algunos individuos del depósito.

Además, otras medidas empeoraron la situación, endureciendo los controles y castigos. Este hecho a veces se correspondía tanto con las derrotas de Napoleón como con un empeoramiento de las condiciones de vida de los presos franceses en terreno extranjero $^{95}$. Asimismo, es probable que fuera un modo de ejercer escarnio y pública reafirmación del poder (como en casos equivalentes se realiza a modo de castigo preventivo) ${ }^{96}$. Proseguía Román: "En tiempo del Calvo Motte siguió la deserción y, para evitarla, o más bien para castigar a los que ninguna culpa teníamos, pusieron dos listas diarias, prohibición de salir de la ciudad, y de andar por ella pasadas las siete o las ocho de la noche ${ }^{97}$. Se castigaba a todos por igual, pese a que fueran cumplidores con las normas del cautiverio. Asimismo, se tendió a reducir el estilo de la vida que tenían de mediana libertad por otras formas más normadas y constrictoras, propias de otros depósitos ${ }^{98}$.

Tales medidas fueron acompañadas de un sistema de vigilancia muy estricto, donde se censuraba la correspondencia y se amenazaba con el castigo de enviar a prisiones militares. Román se quejaba: "El escrutinio de las cartas se hizo en su tiempo más riguroso y, ayudado por la parquedad, mala inteligencia o voluntad de su intérprete Don ..., hubo muchos oficiales destinados a Landau y otros castillos por cosas muy nimias, a veces por cartas que recibían sin que ellos hubiesen dado el menor motivo. Yo estuve baxo la

\footnotetext{
${ }^{93}$ Como sucede con los casos de la televisión o el estudio en las cárceles contemporáneas, que ha señalado: FERREIRA, Jose Manuel: Relações de poder no contexto prisional..., p. 183.

94 AYMES, Jean-René: La déportation sous le Premier Empire, Paris, La Sorbonne, 1993.

${ }^{95}$ FERREIRA, Jose Manuel: Relações de poder no contexto prisional..., p. 203

${ }^{96}$ FERREIRA, José Manuel: Ibidem..., p. 203

${ }^{97}$ ZOZAYA, María; ROMÁN, José Mª: Viaje y prisión del ingeniero..., p. 105.

98 Según refiere AYMES, Jean-René: La deportación..., p. 466.
} 
inmediata inspección de la gendarmería, porque uno me escribió en enigma que iba a

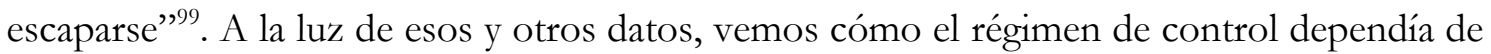
lo estrictos que se pusieran los mandos superiores y, en última instancia, de las decisiones personales arbitrarias (a veces generadas como escarnio o con motivo de las deserciones) ${ }^{100}$.

\section{EL PRISIONERO MÁS LIBRE: EL ALOJADO EN CASAS PARTICULARES}

Después de la temporada destinados en la caserna de Santa Catalina, algunos ingenieros pasaron a casas de particulares, aunque tenían que seguir asistiendo a la caserna para pasar las mencionadas listas o recoger correspondencia. Desde junio de 1809 hasta enero de 1814, Román fue a vivir a una casa particular en Nancy. Le alojó en su casa Monsieur Jean Blau, profesor de humanidades en la Universidad de Nancy, a quien conoció durante los primeros días en la biblioteca pública. Entablaron una grandísima amistad y un estrecho trato. A raíz de los lazos generados por la confianza, ambos desenvolvieron relaciones que pueden ser analizadas desde el enfoque de las redes sociales, donde se entrelazaba el terreno profesional con la amistad, la protección y el padrinazgo ${ }^{101}$. Gracias a Blau, Román entró en clases universitarias privadas, participó en los círculos de sociabilidad de sus profesores, consultó su escogida biblioteca, aprendió la lengua griega clásica y el alemán moderno.

Además, Jean Blau le buscó trabajo cuando su protegido lo necesitó. Román se quejaba de la desfavorable situación en que les dejaba el Estado Francés, que sin embargo fue contrarrestada por la actitud de su amigo: "Quando en febrero de 1812 nos disminuyeron las pagas, dexándonos reducidos á no poder subsistir sino con mucha escasez, me procuró la ocasión de trabajar en copiar los planos del Cadastro, con lo que ganaba algo que añadir á la paga. Pero como este trabajo no me gustaba, y para ganar algo era preciso emplear en ello todo el día con detrimento de mi estudio, me proporcionó de dar lecciones de latino á gentes que él conocía, siendo él quien primero me encargó sus hijos". Tales vínculos personales y profesionales se sellaron en el terreno familiar por lazos de padrinazgo vinculados a los ritos de paso católico, que -según los códigos de la época-

\footnotetext{
${ }^{9}$ ZOZAYA, María; ROMÁN, José Mª: Viaje y prisión del ingeniero..., p. 105.

100 Hubo militares que se escaparon en acciones de cierta envergadura, como la del general Contreras estudiado por GIMENO, Ma Dolores, "El sitio de Tarragona en las memorias del general Contreras", en: CARO, Diego; DURÀN, Fernando (Coords.), Experiencia y memoria de la revolución española, Cádiz, Universidad de Cádiz, 2011, pp. 193-212.

${ }^{101}$ REQUENA, Félix: Análisis de redes sociales, Madrid, S.XXI, 2006.
} 
le integraban de modo definitivo en el cuerpo doméstico de la casa ${ }^{102}$. Aunque Román fue padrino de la última hija de Blau, él mismo señalaba que fueron sus "verdaderos ahijados en el cariño" otros de sus vástagos: su discípulo José, Adolfo y Félix ${ }^{103}$.

Ese mismo tipo de vinculaciones afectivas entre los prisioneros y la persona que les alojaba, se repitieron con posterioridad y abarcaron a sus compañeros. En enero de 1814 los llevaron prisioneros desde Nancy a Normandía. Y una situación equivalente se repitió cuando llegaron al depósito de Caudebec en febrero. Se estableció un régimen de cautividad en casas particulares, con cuyos propietarios establecieron fuertes lazos. Román se alojó en casa del señor le Sage, a quien debió "muchos favores". Les unieron fuertes vínculos de amistad ramificados en diversos terrenos. Incluso se tradujeron en una fuerte protección que llegó a poner en peligro su instinto de supervivencia. Fue en abril de 1814, cuando ordenaron que los prisioneros saliesen hacia Caen dirigidos por los ejércitos napoleónicos. Pero, como los aliados ya habían tomado París, monsieur le Sage le propuso a Román que cambiase su plan: "se empeñó en conservarme oculto en su casa hasta la decisión final. Habiéndole representado que no podía separarme de mis amigos, tuvo la generosidad de hacerlos quedar igualmente". De ese modo, puso en peligro su propia seguridad, arriesgando su vida por ocultar a varios de los prisioneros españoles. Exteriorizó ese instinto de protección también por la vía económica, cuando tras la victoria aliada salieron hacia París. Román contaba: "El generoso Monsieur le Sage, viendo que carecía de dinero, me hizo tomar por fuerza ocho luises para el viage. Por todos estos favores y el buen trato que experimenté en su casa le estaré enteramente agradecido, así como á su señora y hermano" ${ }^{104}$. Es decir, que de nuevo la experiencia de prisión quedaba como una cuestión positiva, siembre y cuando dependiese de las redes sociales trazadas, de los valores humanos o las amistades establecidas con los franceses. Aspectos que sería difícil descubrir en etapas en que desde el Estado se quisieran fomentar sentimientos de enemistad contra el país vecino o de naturaleza nacionalista (fuese por Fernando VII o ya a la altura de 1900).

\section{COLOFÓN. UNA IMAGEN DE LA PRISIÓN MÁS POSITIVA}

En las presentes páginas se señala cómo el análisis de las campañas napoleónicas y contra la invasión francesa ha dejado olvidado el tema de los prisioneros de guerra. En especial, los prisioneros conducidos prisioneros a Francia, el grado medio de la jerarquía de los

102 IMÍZCOZ, José Ma: "Familia y redes sociales en la España Moderna”, en LORENZO, Francisco J. (Ed.), La Familia en la Historia, Salamanca, Universidad de Salamanca, 2009, p. 139.

${ }^{103}$ ZOZAYA, María; ROMÁN, José Mª : Viaje y prisión del ingeniero..., pp. 102-103.

104 ZOZAYA, María; ROMÁN, José Ma: Ibidem..., p. 123. 
suboficiales. Su tratamiento no es sencillo, dada la escasez de fuentes de naturaleza privada al respecto. Sin embargo, cuando esta cuestión se consigue rescatar del olvido con estudios de caso como el presente, se reflejan situaciones de gran interés para el conocimiento de los desplazamientos de prisioneros y del cautiverio bélico; muestran momentos aparentemente paradójicos, en especial cuando algunos pasajes de la experiencia en prisión fueron muy positivos.

En estas páginas se hace hincapié en los aspectos positivos a través de los espacios de reclusión y el régimen del mismo. Primero, se muestran los espacios cotidianos donde pasaron su cautiverio los suboficiales tras el sitio de Zaragoza, estuviesen prisioneros en Francia bien en casernas, bien en fonda, bien en residencias de particulares. Al contrastar esas escenas de prisión con imágenes de fotografías postales de 1900 en Nancy, se muestran unas casernas neoclásicas con infraestructuras de bastante calidad. Segundo, se tratan elementos de la prisión de élite, como el laxo régimen de vigilancia inicial, donde el límite lo ponía la "ciudad prisión” y el juramento del honor de no escaparse, o las buenas condiciones materiales de vida. Tercero, se manifiesta la relación estrecha que establecieron los prisioneros con los propios dueños de las casas donde se alojaron. La imagen que resulta del estudio de la prisión de los suboficiales, cambia mucho el concepto que predomina del cautiverio en el común de las mentalidades colectivas.

Este trabajo muestra cómo las formas de vida en cautividad resultaron mucho más positivas para muchos prisioneros de lo que tiende pensarse a priori. Sin embargo, incluso en ámbitos académicos predominan imágenes anacrónicas de lo que supuso el cautiverio de élite. Esa deformación se debe, a mi juicio, a tres cuestiones vinculadas a la ocultación de la memoria. La primera, a la escasez de fuentes primarias con narrativas similares, por la dificultad de escribir en tiempo de guerra y prisión. Segundo, por el miedo a sufrir procesos de purificación por Fernando VII, por dado el trato negativo que ya sufrieron sólo por haber pasado cinco años cautivos en el país vecino. Tercero, a la escasez de estudios que existe en el ámbito de los prisioneros de guerra en la época napoleónica, con el subsecuente desconocimiento que le sigue. Con la realidad que se saca a la luz en el presente análisis se pone aún más de relieve la necesidad de estudiar ese vacío en materia punitiva para acabar con aparentes mitos tal vez anacrónicos y contribuir a recomponer las piezas de ese puzle desconocido de la Historia Social de la época.

El análisis del fenómeno en general puede estar hablando de un modelo de cautiverio de la elite de segunda fila. Un patrón vinculado al respeto de los códigos de honor y al mantenimiento de los privilegios perpetuados en el mundo del Antiguo 
Régimen. La imagen aquí ofrecida del régimen de vida de los prisioneros de guerra entre 1809 y 1814 refleja que el modelo de prisión de guerra de la élite continuaba el sistema propio de la Edad Moderna. A mi juicio, si se encontraran y sacaran a la luz más experiencias de estos personajes en sus años de prisión en Francia, se mostraría que hay un modelo de cautiverio silenciado. Asimismo, que dentro de él hay facetas que pueden ser estudiadas desde la perspectiva de las redes sociales y la Historia de los sentimientos, que pueden alumbrar sobre nuevas imágenes antes no contempladas para abordar el tema de los prisioneros. 


\section{APÉNDICE DE IMÁGENES}

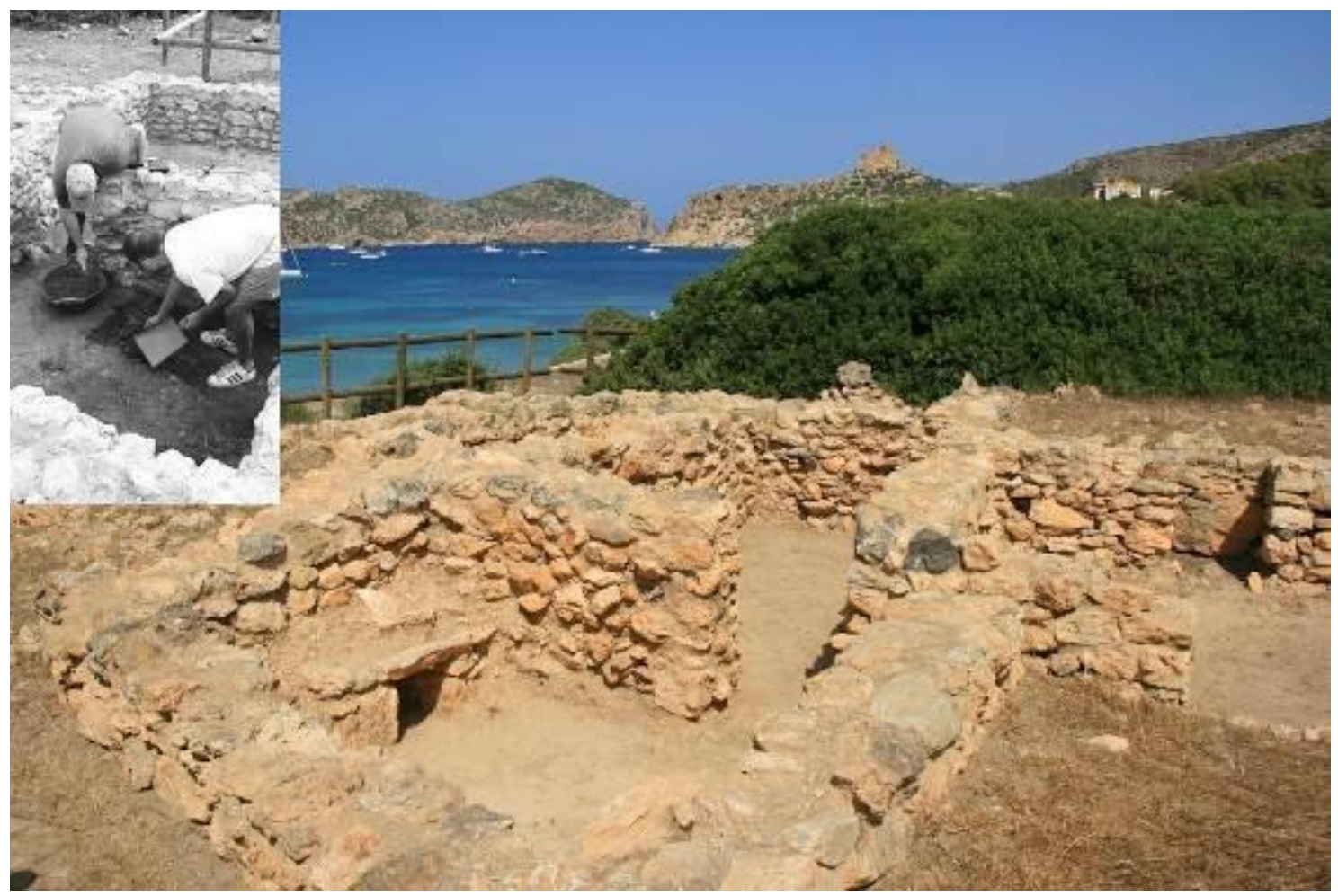

Imagen 1. Barracas de los prisioneros de época napoleónica. Isla de Cabrera, Mallorca. Collage preparado por María Zozaya con fotografía de las excavaciones.

Foto izquierda: http://bit.ly/Zbo6pW ; Foto derecha: Carloso (Panoramio)

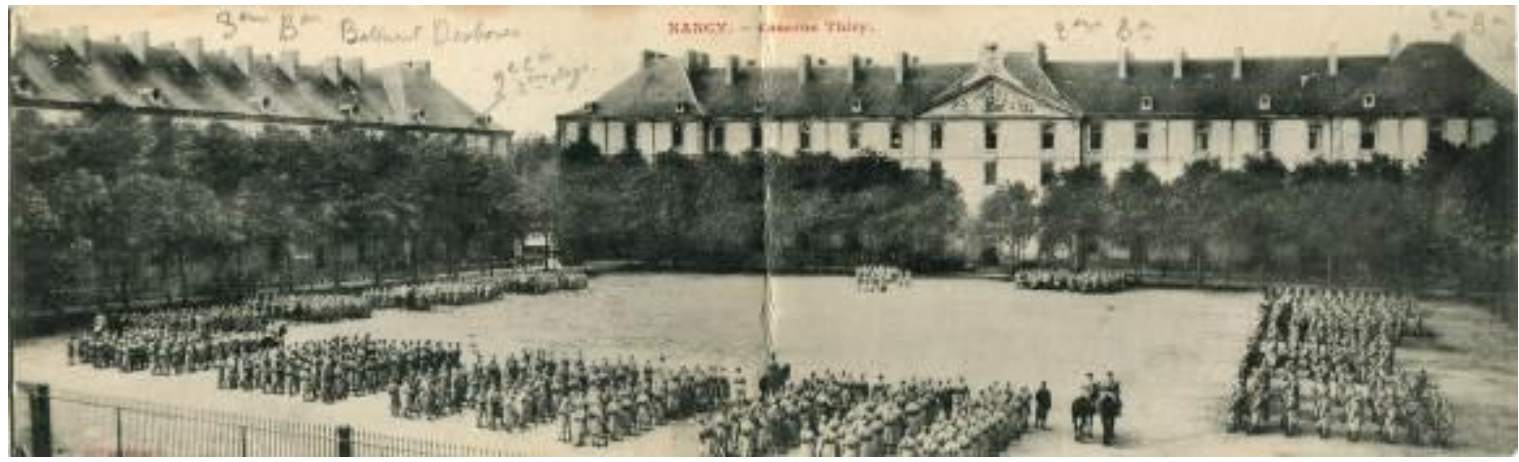

Imagen 2. Caserna Thiry (Nancy, Francia). Caserna principal y lateral con militares formando en el patio. Fuente: Colección privada Pierre Boyer. 


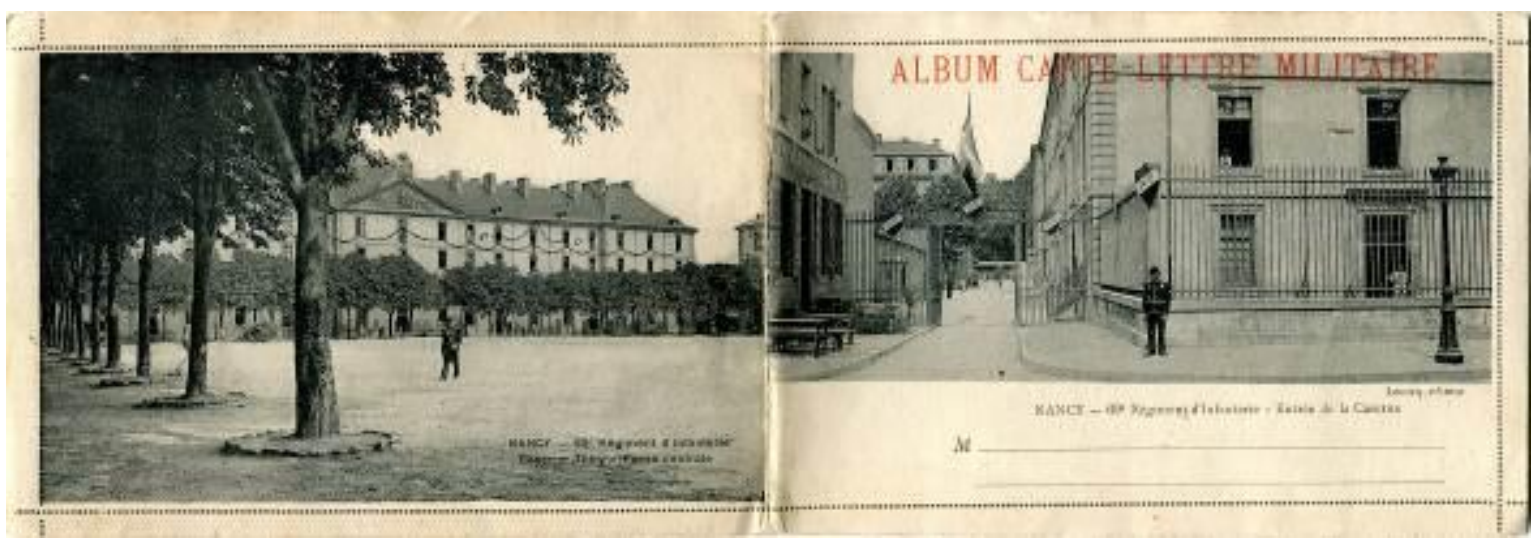

Imagen 3. La caserna principal vista desde el patio y entrada lateral. Postal que, al estar unida a la imagen de la caserna Thiry que ya reconocíamos y, al estar escrito que albergaba al regimiento 69, nos permitió identificar más estancias de este espacio de cautiverio.

Fuente: Colección privada Pierre Boyer.

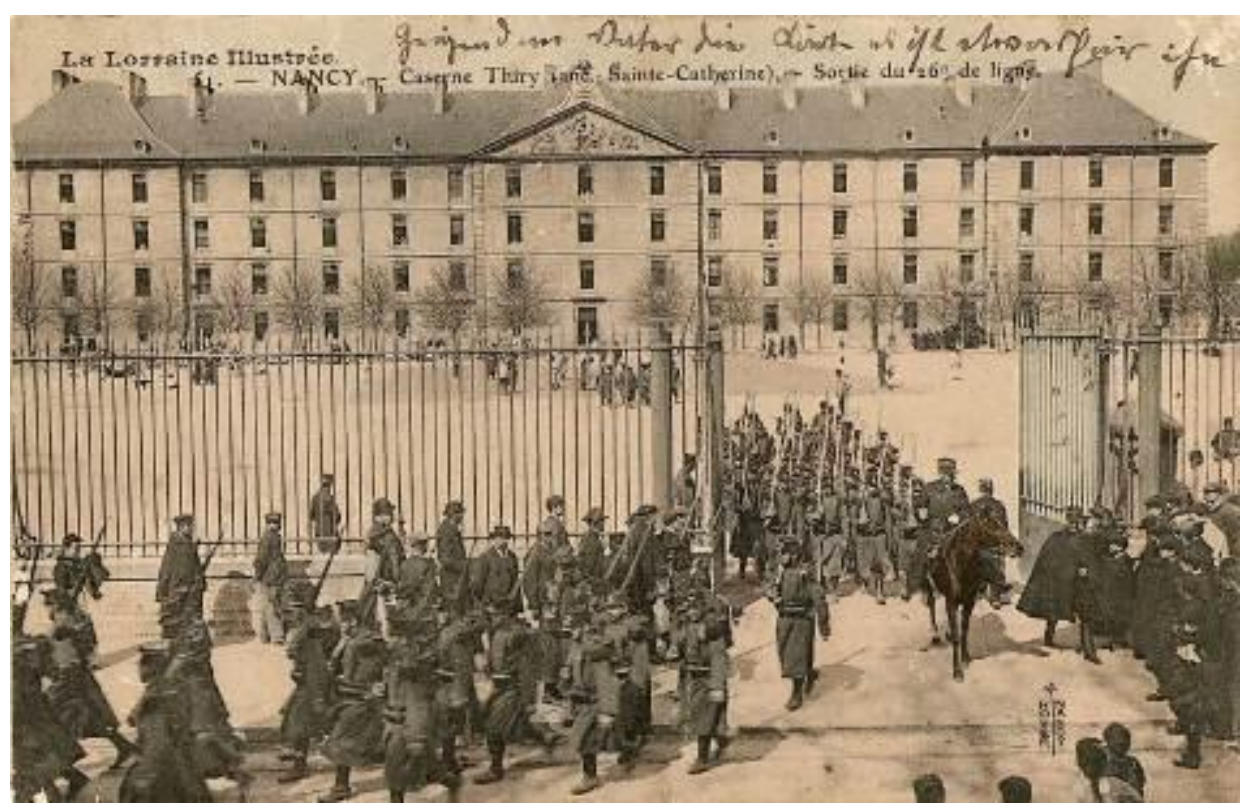

Imagen 4. Detalle del cuerpo frontal con militares. Única postal donde se registran los dos nombres de la Caserna. Fuente: Colección privada Pierre Boyer. 


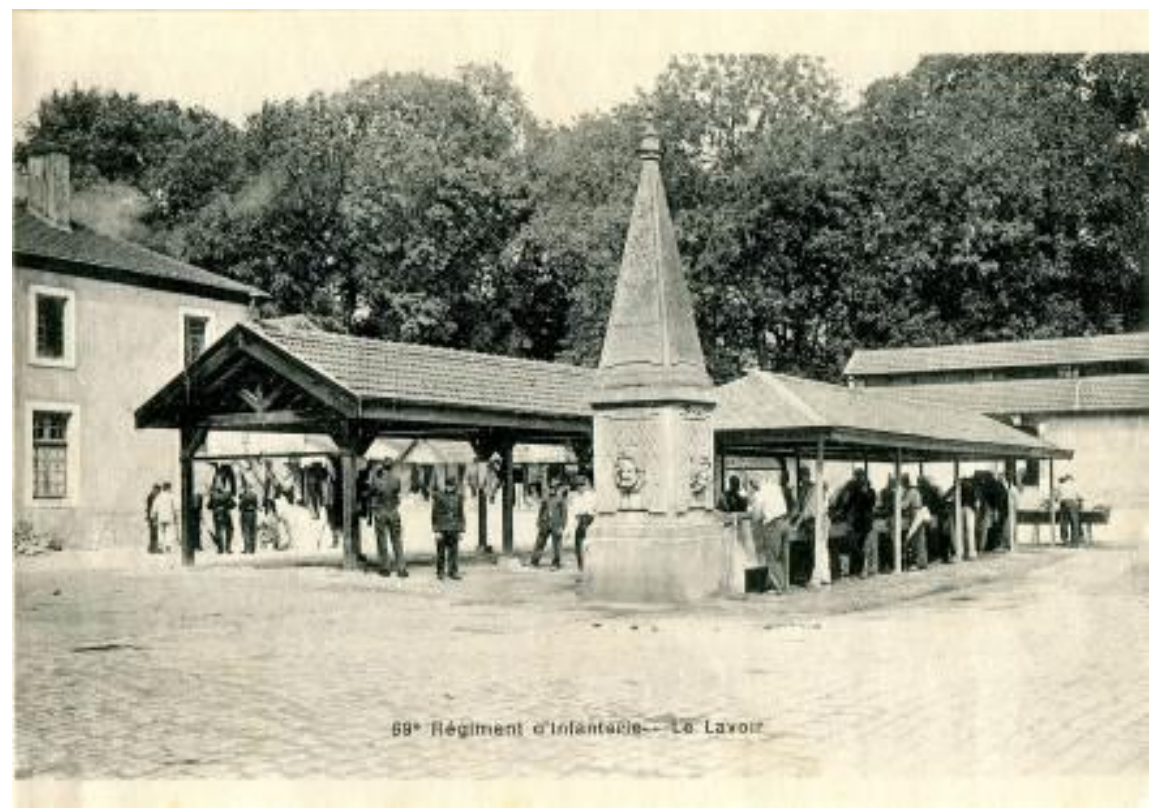

Imagen 5. Fuente y lavadero de la Caserna Thiry. Fuente: Colección privada Pierre Boyer

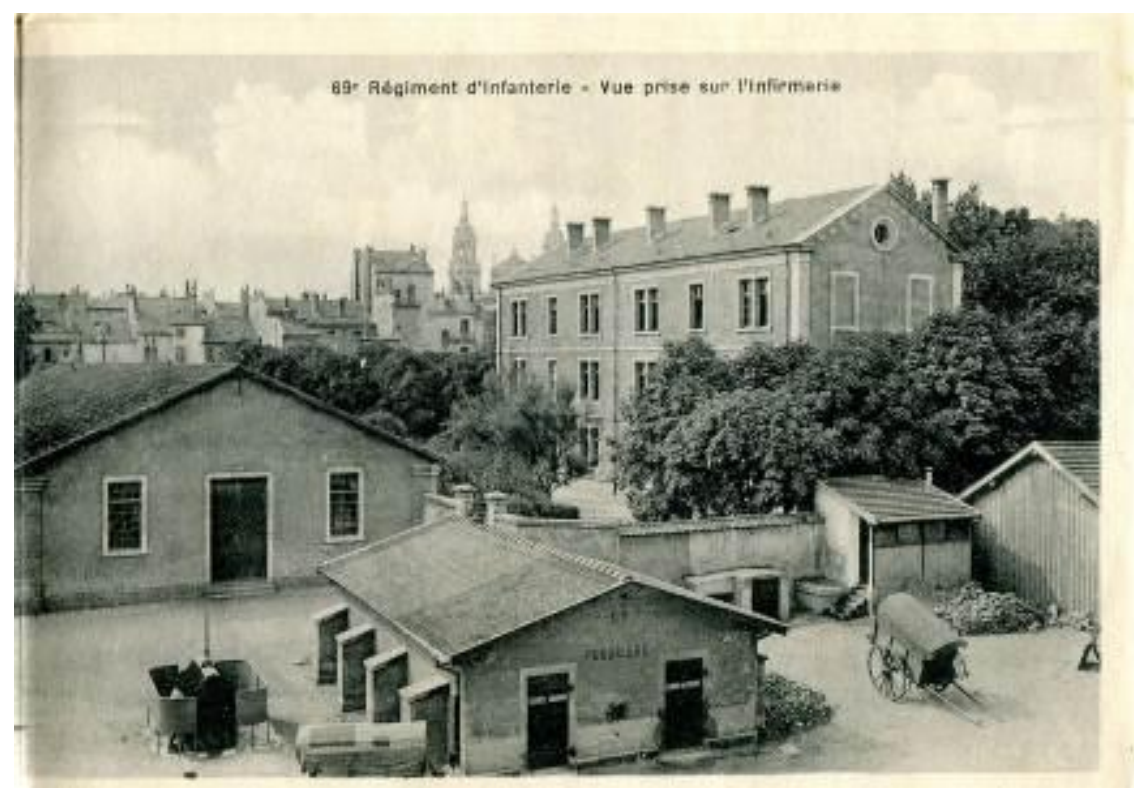

Imagen 6. A la izquierda, los urinarios de la caserna Thiry, en el centro, la enfermería. Fuente: Colección privada Pierre Boyer. 


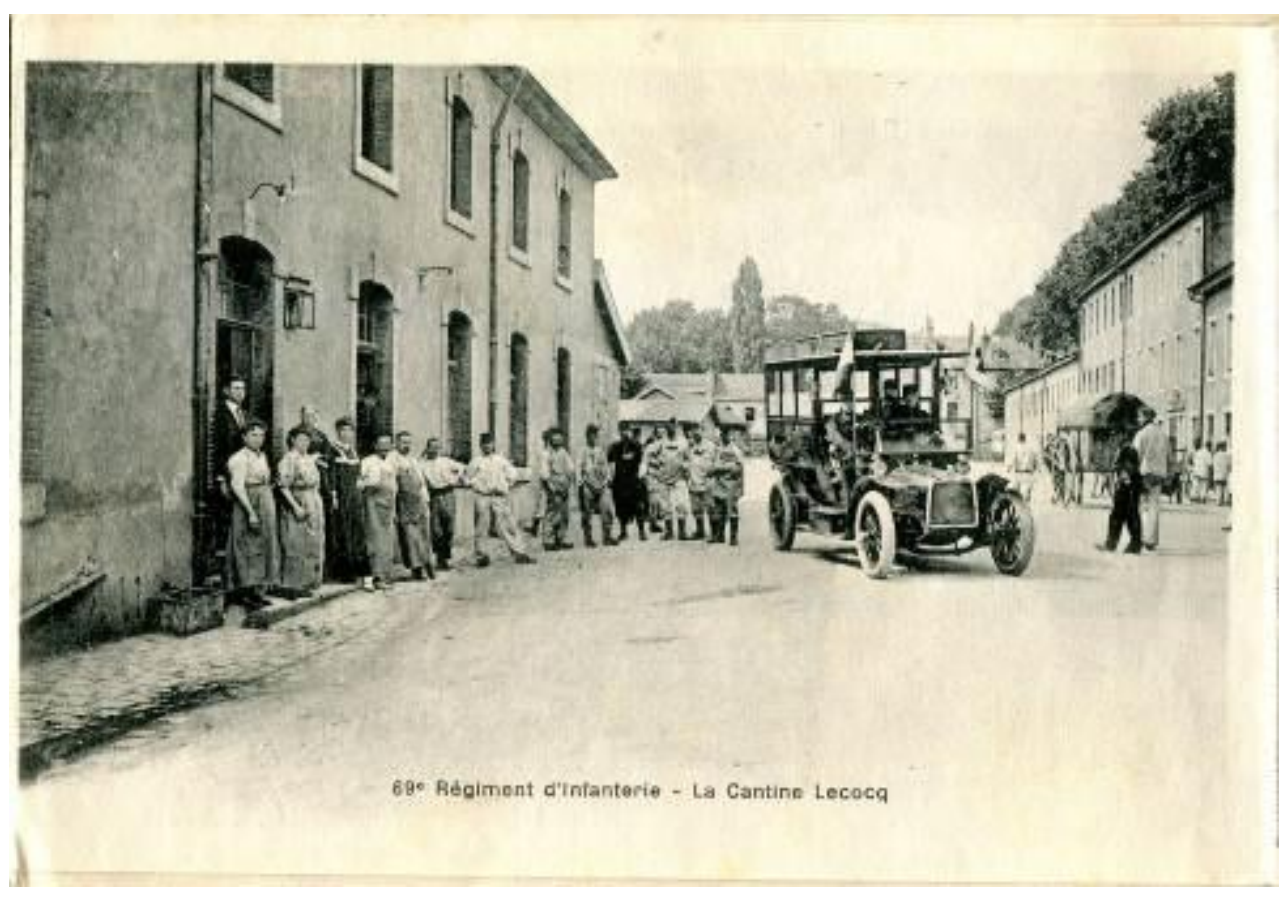

Imagen 7. Cantina de la caserna, denominada "Le cocq". Fuente: Colección privada Pierre Boyer

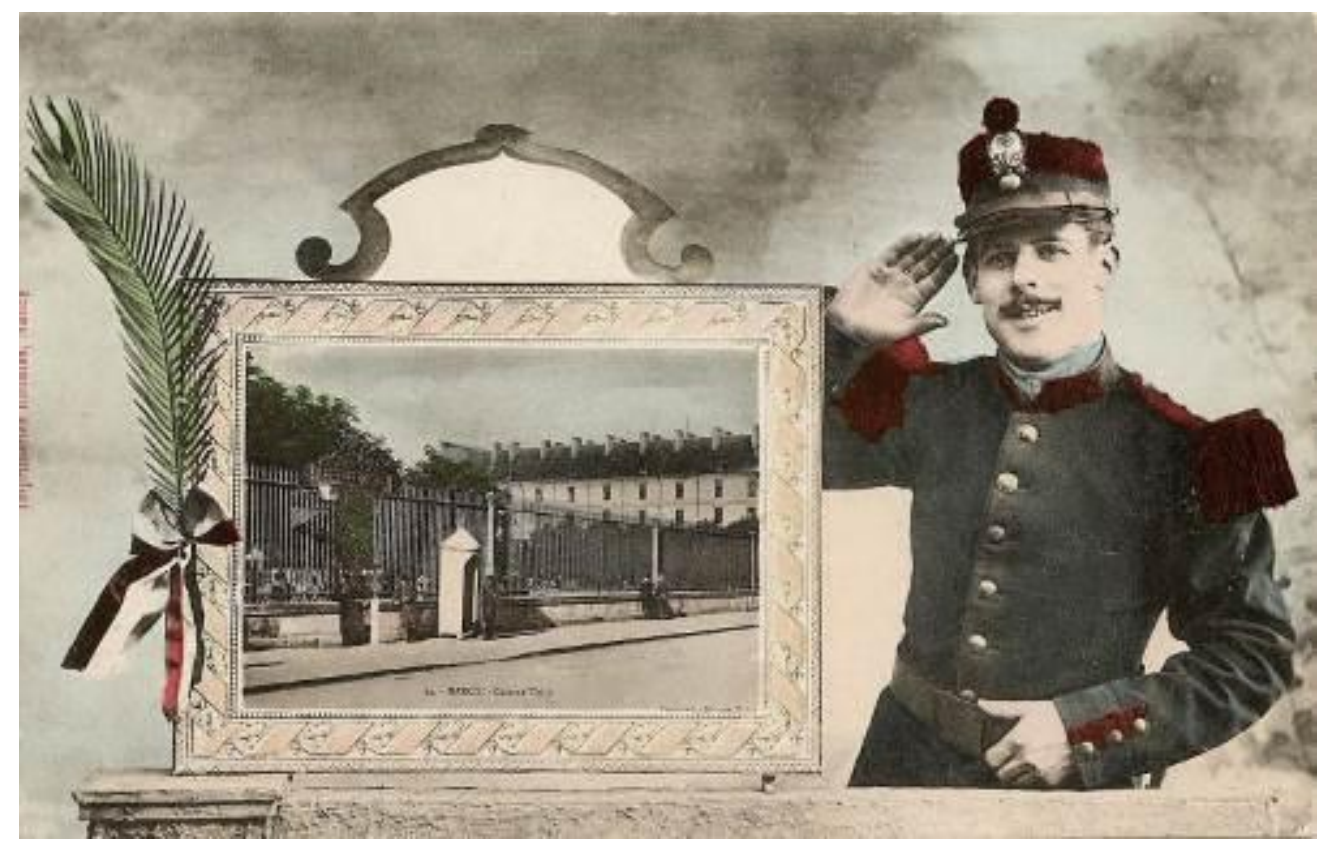

Imagen 8. Militar retratado junto a la Caserna Thiry.

Fuente: Colección privada Pierre Boyer 


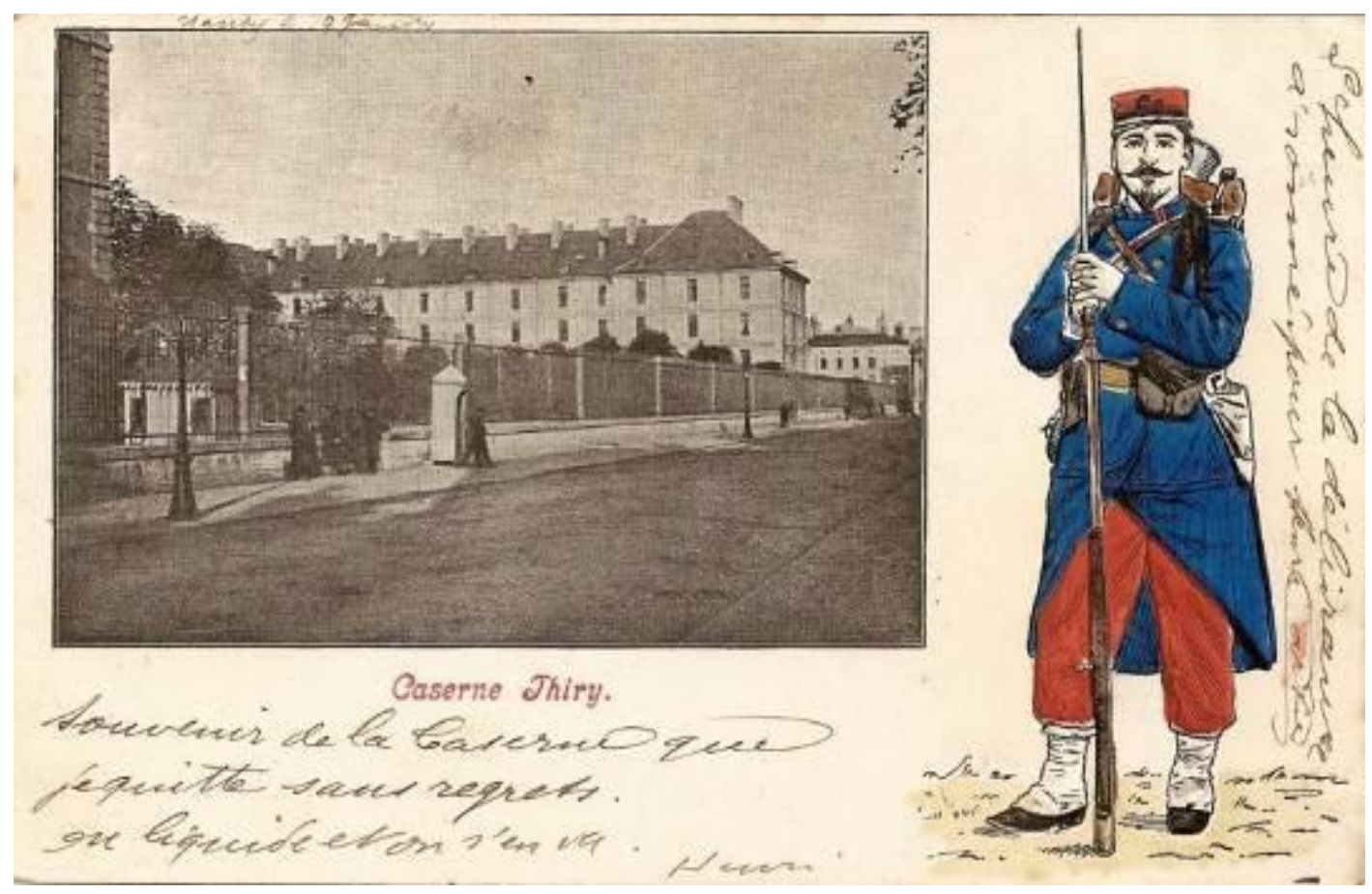

Imagen 9. Postal en que un soldado se queja de la caserna Thiry 